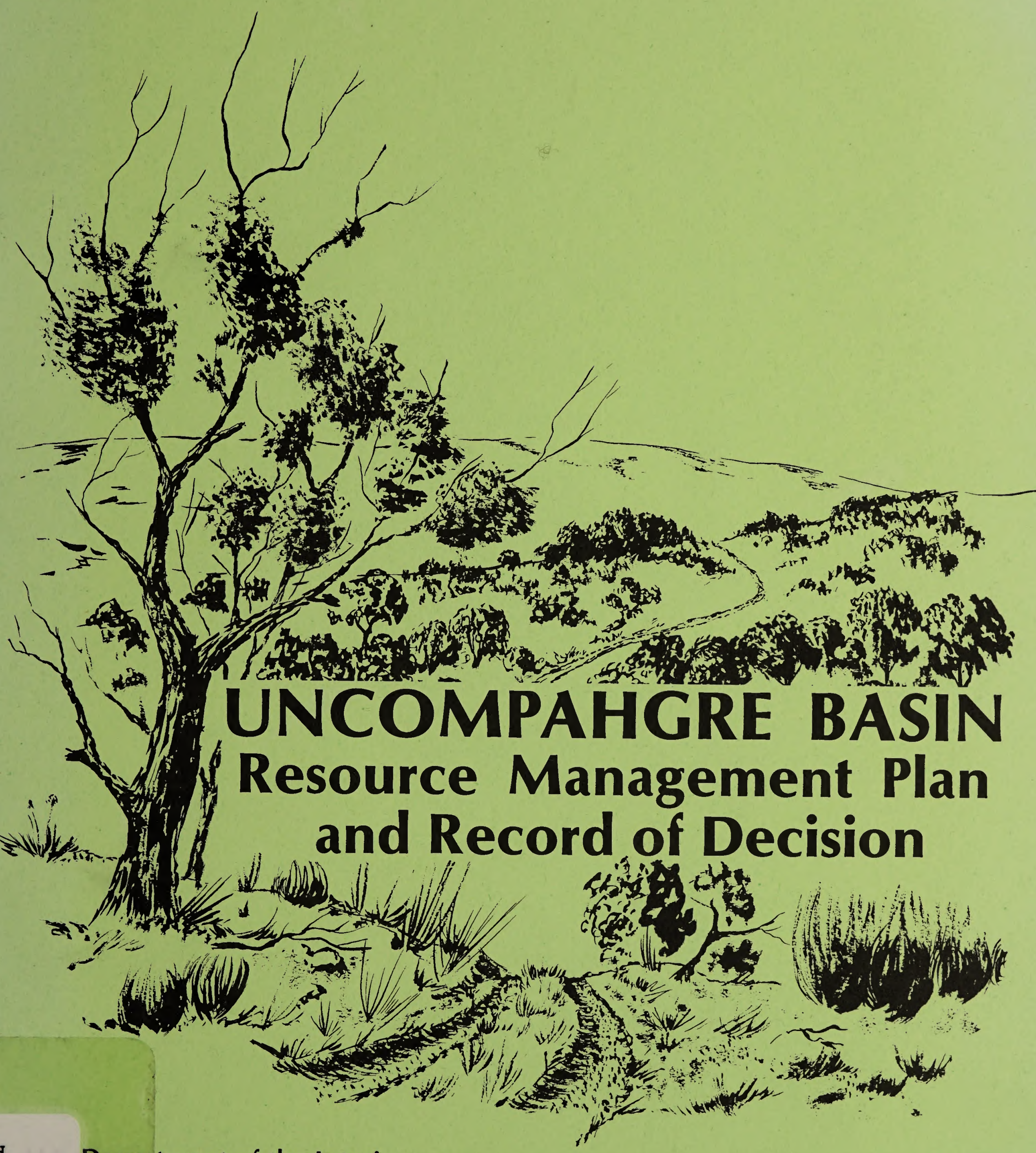

$\mathrm{QH}$

76.5

C 6
U526

Department of the Interior au of Land Management

1989 trose District, Colorado ompahgre Basin Resource Area

c. 3 
BLM Library

Denver Federal Center

Bldg. 50, OC -521

P.O. Box 25047 


\section{RECORD OF DECISION \\ UNCOMPAHGRE BASIN RESOURCE MANAGEMENT PLAN}

U. S. Department of the Interior

Bureau of Land Management

Montrose District

Uncompahgre Basin Resource Area 

RECORD OF DECISION

\section{UNCOMPAHGRE BASIN RESOURCE MANAGEMENT PLAN}

T his document records the decisions reached by the Bureau of Land Management (BLM) for managing 483,077 surface acres of public land and 755,923 acres: (including those beneath the surface acres) of federal mineral estate within the approximately. 1.38 million acre Uncompahgre Basin Planning Area.

\section{DECISION}

$T^{1}$ he Uncompahgre Basin Resource Management Plan (RMP) as described in Chapter Two of the attached RMP is approved. The plan was prepared under the regulations for implementing the Federal Land Policy and Management Act (FLPMA) of 1976: (43 CFR 1600). An environmental impact statement was prepared for this plan in compliance with the $\mathrm{Na}$ tional Environmental Policy Act (NEPA) of 1969. The plan described in Chapter Two of the attached RMP reflects the proposed plan as set forth in the proposed plan and associated final environmental impact statement published in September 1988.

\section{ALTERNATIVES CONSIDERED:}

$\mathbf{F}$ our alternatives for managing the resources within the planning area were considered in the development of the plan. These were identified as the Continuation of Current Management Alternative, the Production Alternative, the Conservation Alternative, and the Preferred Alternative. Each alternative was described and analyzed in the draft RMP/EIS and proposed RMP/final environmental impact statement.

The Continuation of Current Management Alternative maintained present management direction utilizing existing Management Framework Plan decisions. This alternative was the No Action Alternative required by the National Environmental Policy. Act.

The Production Alternative was designed to continue multiple-use management of the public lands with the objective of promoting the development, production, and transportation of those resources which provide minerals; food, timber and fiber.

The Conservation Alternative was designed to continue multiple-use management of the public lands with the objective of promoting conservation and protection of resources such as wilderness, cultural sites, wildlife habitats; watersheds, and recreation areas.

The Preferred Alternative was developed based on an analysis of the other three alternatives. It was: modified as a result of public input and became the Proposed Plan accompanied by the final environmental impact statement. The Proposed Plan (Preferred Alternative) is the environmentally preferable alternative. No protests were received on this proposed plan/Final EIS and it has been selected as the Un compahgre Basin Resource Management Plan. This alternative (as well as the other alternatives) proposes areas for special designations. The 
final decision, as described in Chapter Two of the attached RMP, selects four areas for special designatlon. These areas are the Escalante Canyon ACEC (Management Unit 12) 1895 acres; the Fairview RNA/ACEC (Management Unit 13) 377 acres, the Needle Rock ONAVACEC

(Mangement Unit 14) 80 acres and the Adobe Badlands ONAIACEC (Management Unit 15) 6783 acres:

\section{MITIGATION}

The RMP has been designed to avold or minImize adverse environmental effects to the extent posslble. Specific mitigation measures: are descrlbed by management unit in Chapter Two of the attached RMP.

\section{MONITORING}

A monitoring program which includes two A levels of monitoring has been developed for the RMP. The first level of monitoring is designed to track the implementation of the plan and is outlined in Chapter One of the RMP. The second level of monitoring is designed to assure that the desired results of the plan are being achieved and to identify needed management changes if they are not. This second level is described in Chapter Three of the attached plan by resource.

July 26, 1989

Date

\section{PUBLIC INVOLVEMENT}

The views of the public have been sought throughout the planning and decisionmaking process. Public participation is summarized in Chapter One of the RMP.

\section{CONSISTENCY}

The plan is consistent with plans and policies of state and local governments; of other federal agencies, and of the Department of the Interior.

\section{AVAILABILITY OF THE.PLAN}

ropies of the Uncompahgre Basin Resource Management Plan are available from the Area Manager, Bureau of Land Management, Uncompahgre Basin Resource Area, 2505 South Townsend Avenue, Montrose, Colorado 81401, telephone (303) 249-7791. Copies may also be obtained from the BLM'Montrose District Office, 2465 S. Townsend Avenue, Montrose, Colorado 81401 or from the BLM Colorado State Office, 2850 Youngfield Street, Lakewood, Colorado 80215.

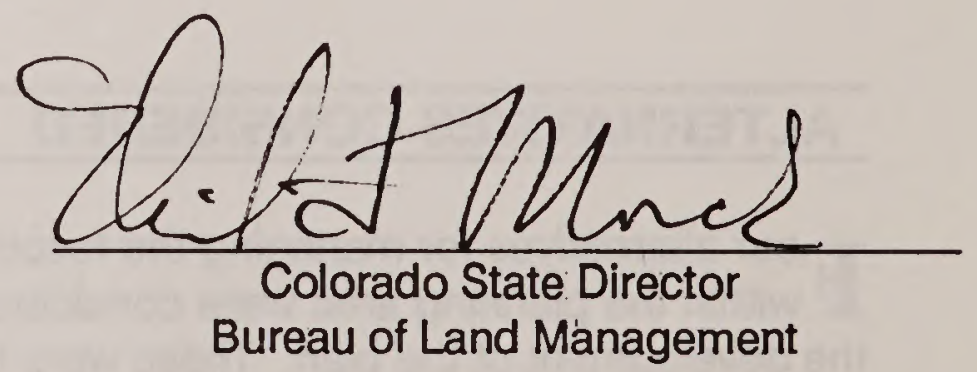




\section{UNCOMPAHGRE BASIN}

\section{RESOURCE MANAGEMENT PLAN}

Prepared by

U. S. Department of the Interior

Bureau of Land Management

Colorado State Office

Montrose District

Uncompahgre Basin Resource Area

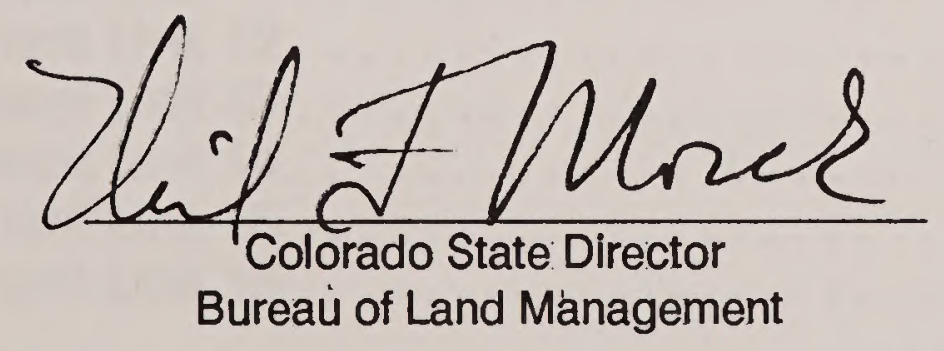

July 26, 1989

Date 



\section{TABLE OF CONTENTS}

CHAPTER ONE - INTRODUCTION $\ldots \ldots \ldots \ldots \ldots \ldots \ldots \ldots \ldots \ldots$

Purpose and need $\ldots \ldots \ldots \ldots \ldots \ldots \ldots \ldots \ldots \ldots \ldots \ldots \ldots$

Relationship to other BLM Planning Levels . . . . . . . . . . . . . 1

Setting .............................

Implementation ............................ 5

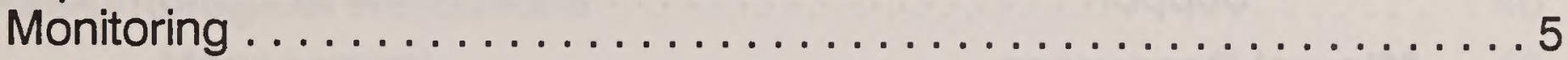

Maintenance .............................. 5

Amendments and Revisions $\ldots \ldots \ldots \ldots \ldots \ldots \ldots \ldots \ldots$

Valid Existing Rights ......................... 5

Public Involvement and Intergovernmental/Interagency Coordination . . .5

Planning Issues and Associated Resource Decisions . . . . . . . . . 7

\section{CHAPTER TWO - UNCOMPAHGRE BASIN RESOURCE} MANAGEMENT DECISIONS

Assumptions $\ldots \ldots \ldots \ldots \ldots \ldots \ldots \ldots \ldots \ldots \ldots \ldots$

Standard Management Direction $\ldots \ldots \ldots \ldots \ldots \ldots \ldots \ldots \ldots$

Disposal of Public Lands . . . . . . . . . . . . . . . . . 11

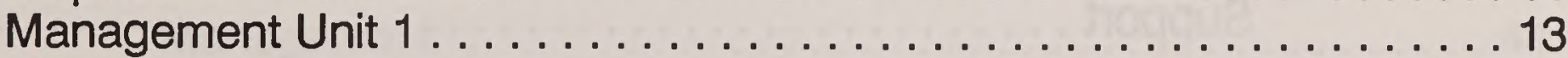

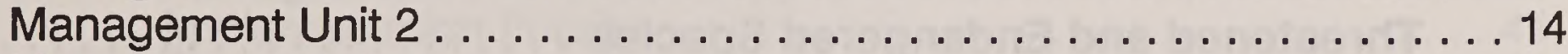

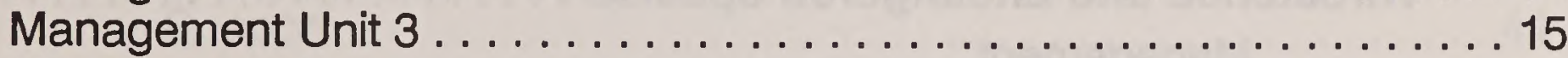

Management Unit $4 \ldots \ldots \ldots \ldots \ldots \ldots \ldots \ldots \ldots \ldots \ldots \ldots \ldots$

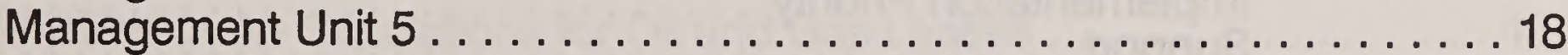

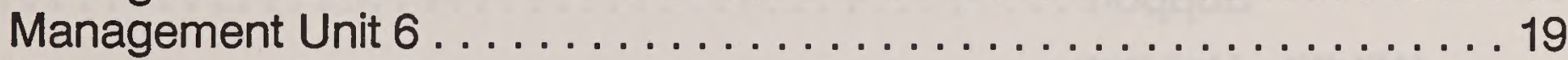

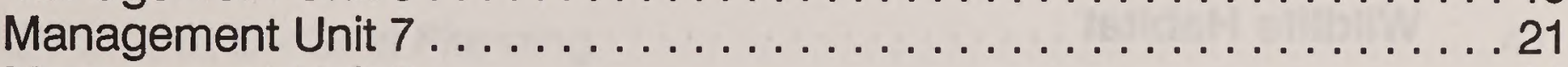

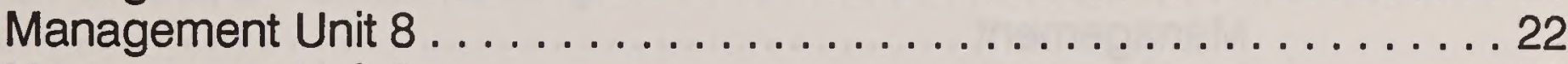

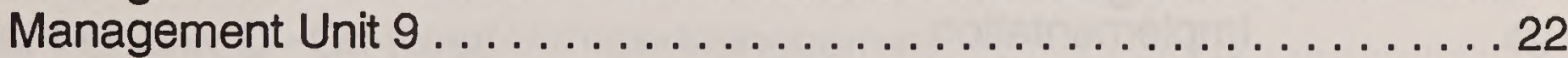

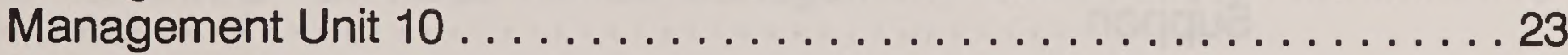

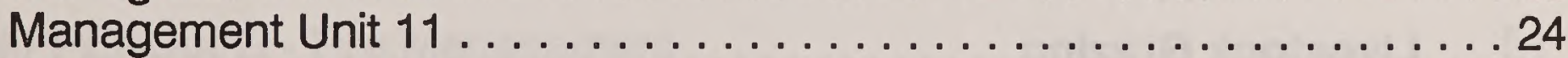

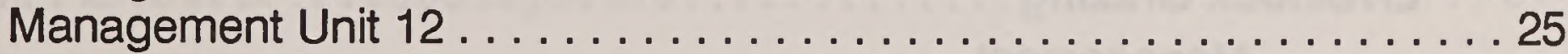

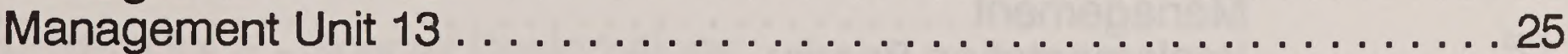

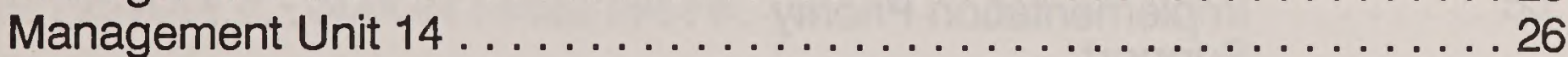

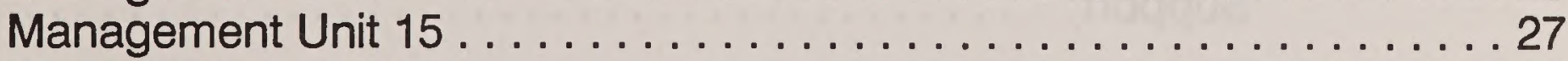

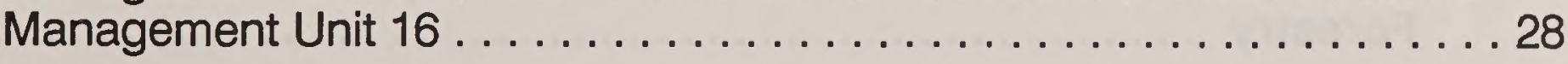




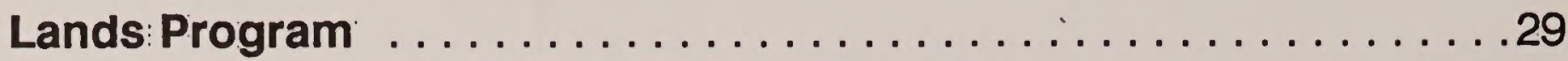

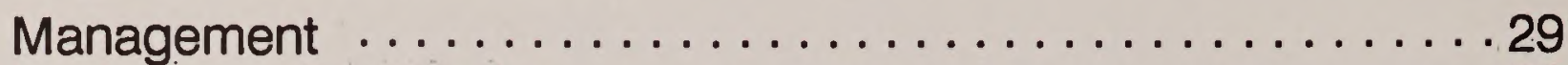

Implementation Priority . . . . . . . . . . . . . . . . 30

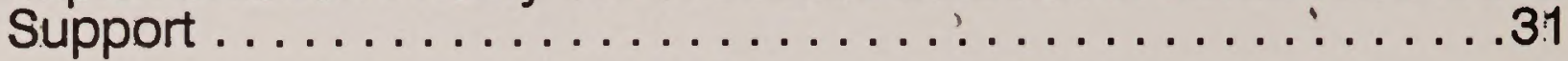

Air Quality . . . . . . . . . . . . . . . . . . . . . 31

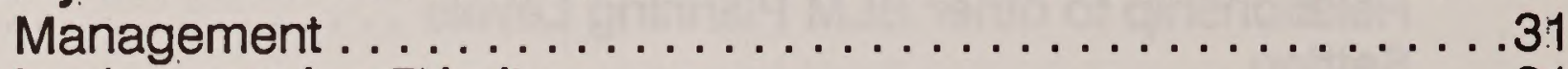

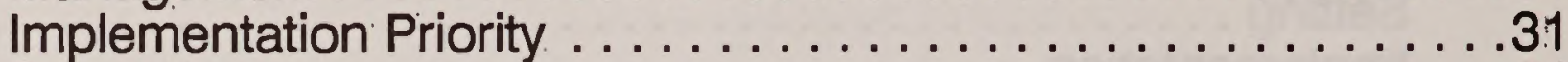

Support .............................

Mineral Resources . . . . . . . . . . . . . . . . . . .31

Management . . . . . . . . . . . . . . . . . . . . .31

Implementation Priority . . . . . . . . . . . . . . . . .3

Support ..............................

Soil and Water Resources $\ldots \ldots \ldots \ldots \ldots \ldots \ldots \ldots \ldots \ldots \ldots$

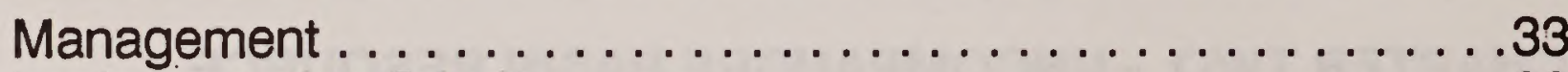

Implementation Priority . . . . . . . . . . . . . . . . .

Support .......................

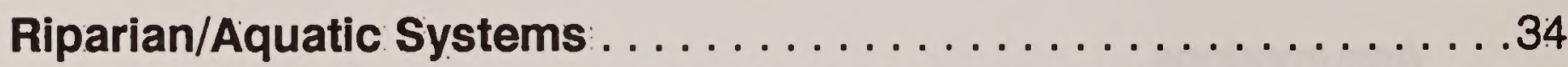

Management ...............................

Implementation Priority . . . . . . . . . . . . . . . . .34

Support ............................ 34

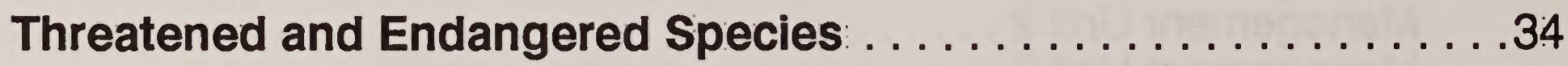

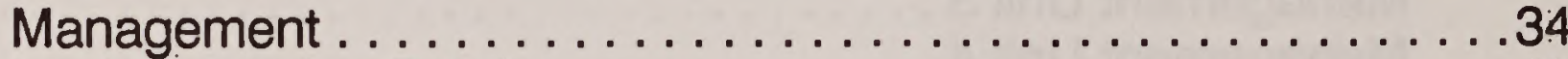

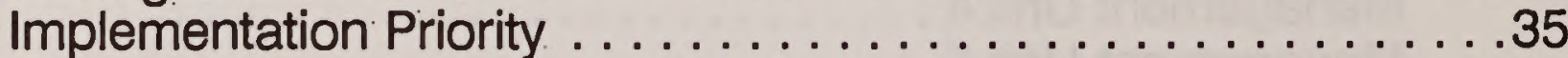

Support ..............................

Wildlife Habitat . . . . . . . . . . . . . . . . . . . . . 35

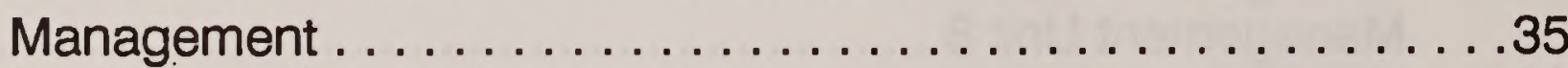

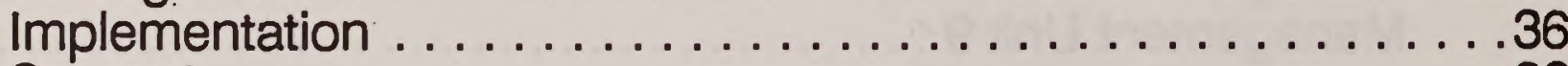

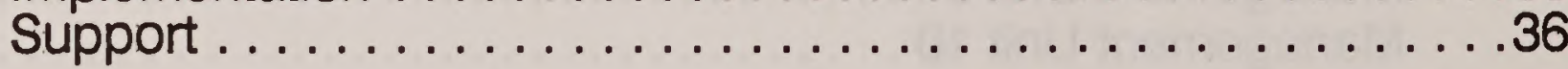

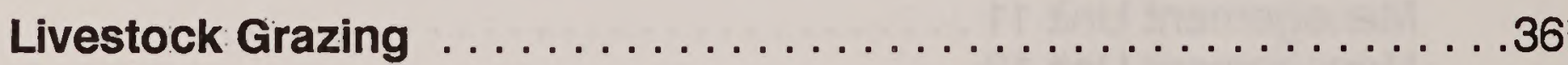

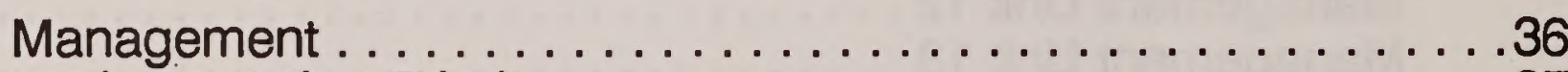

Implementation Priority . . . . . . . . . . . . . . . 37

Support $\ldots \ldots \ldots \ldots \ldots \ldots \ldots \ldots \ldots \ldots \ldots \ldots \ldots \ldots \ldots \ldots \ldots$

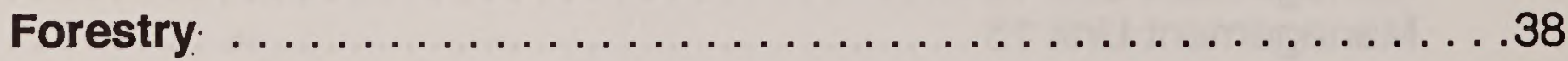

Management .............................

Implementation Priority . . . . . . . . . . . . . . . . .

Support ........................

Recreation ..............................

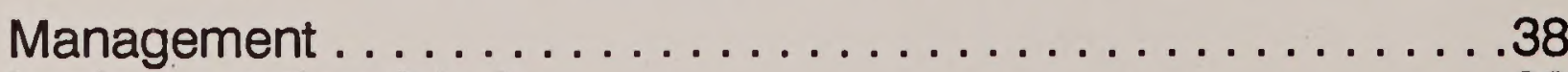

Implementation Priority . . . . . . . . . . . . . . . . .39

Support ............................. 
Off-Road Vehicle Management

Management ........................... 39

Implementation Priority . . . . . . . . . . . . . . . . 39

Support ......................... 40

Cultural Resources . . . . . . . . . . . . . . . . . . . . . . . . . 40

Management ........................... 40

Implementation Priority . . . . . . . . . . . . . . . . . 40 40

Support ..........................40

Paleontological Resources: . . . . . . . . . . . . . . . . . 40

Management ........................40

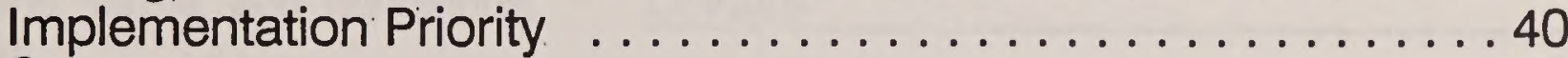

Support ...........................40

Visual Resources . . . . . . . . . . . . . . . . . . . 40

Management ........................40

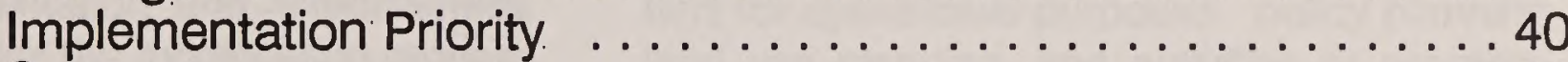

Support ......................... 41

Wilderness . . . . . . . . . . . . . . . . . . . . . 41

Management ........................41

Implementation Priority . ..................41

Fire ...................................44

Management .......................41

Implementation Priority . . . . . . . . . . . . . . . 41

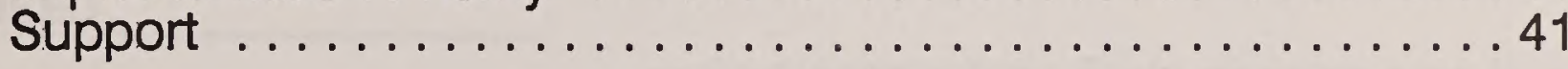

APPENDIX A - Stipulations for Oil and Gas Leases . . . . . . . . . 43

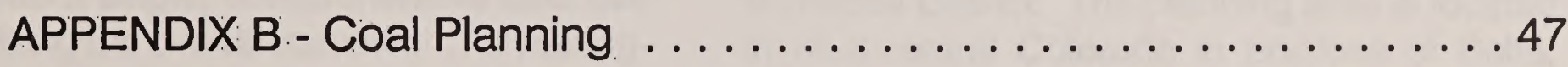

APPENDIX C - Off-Road Vehicle Management ............ 49

APPENDIX D - Fire Management $\ldots \ldots \ldots \ldots \ldots \ldots \ldots \ldots \ldots \ldots \ldots \ldots \ldots$

APPENDIX E - Special Designations . . . . . . . . . . . . . 55: 


\section{CHAPTER ONE}

\section{INTRODUCTION}

T his Resource Management Plan (RMP) contains the land use decisions, terms, and conditions for guiding future management actions within the Uncompahgre Basin Planning Area. All uses and activities within this area shall conform to the decislons, terms, and conditions, described in thls plan.

The RMP describes Implementation priorities by resource as well as monitoring which will track plan implementation and effectiveness. The RMP also outlines the modification process should changes to present decisions be needed.

In addition to this RMP, a final wilderness environmental impact statement (EIS) and wilderness study report (WSR) are being prepared. The final EIS and WSR will be submitted to Congress for legislative action.

\section{PURPOSE AND NEED}

$\mathbf{T}$ he primary purpose of the RMP is to update and integrate the BLM's land use planning for the area into a single, comprehensive land use plan providing the overall framewor'. :or managIng and allocating public land resources in the Uncompahgre Basin planning area over the next ten to twelve years.

In addition to identifying management direction within the planning area, the RMP meets several specific objectives. It (1) identifies federal coal lands that are acceptable for further leasing consideration, acceptable for further leasing consideration with stipulations, or unacceptable for leasing; (2) analyzes the suitability of three Wilderness Study Areas (WSAs) for inclusion into the National Wilderness Preservation Sys- tem (NWPS); and (3) identifies public land to be designated as open, closed, or limited to off-road vehicle use.

\section{RELATIONSHIP TO OTHER BLM PLANNING LEVELS}

evelopment of a RMP occurs within the framework of the BLM planning system. The planning system is subdivided into three dlstinct tlers for operational purposes: policy planning, land use planning, and activities or programspecific planning. The Council on Environmental Quality regulations provided for tiering to aid compliance with the National Environmental Policy Act (40 CFR 1500-1508). This plan satisfies the requirements for the land-use tier of planning.

\section{SETTING}

$T^{\text {he }}$ Uncompahgre Basin planning area is a geographic division of the Uncompahgre Basin Resource Area (UBRA) of the BLM's Montrose Distrlct. The planning area is located in west-central Colorado in portions of Delta, Gunnison, Mesa, Montrose, and Ouray countles (See Figure 1-1). It is bordered In part by the Grand Mesa, Uncompahgre, and Gunnison Natlonal Forests. Figure 1-2 depicts the planning area boundaries.

The planning area encompasses approximately 1.38 million acres. The BLM has administrative responsibility for the public lands and resources on 483,077 surface acres and 755,923 acres of subsurface federal mineral estate. Table 1 details surface and subsurface ownership within the planning area by county. 


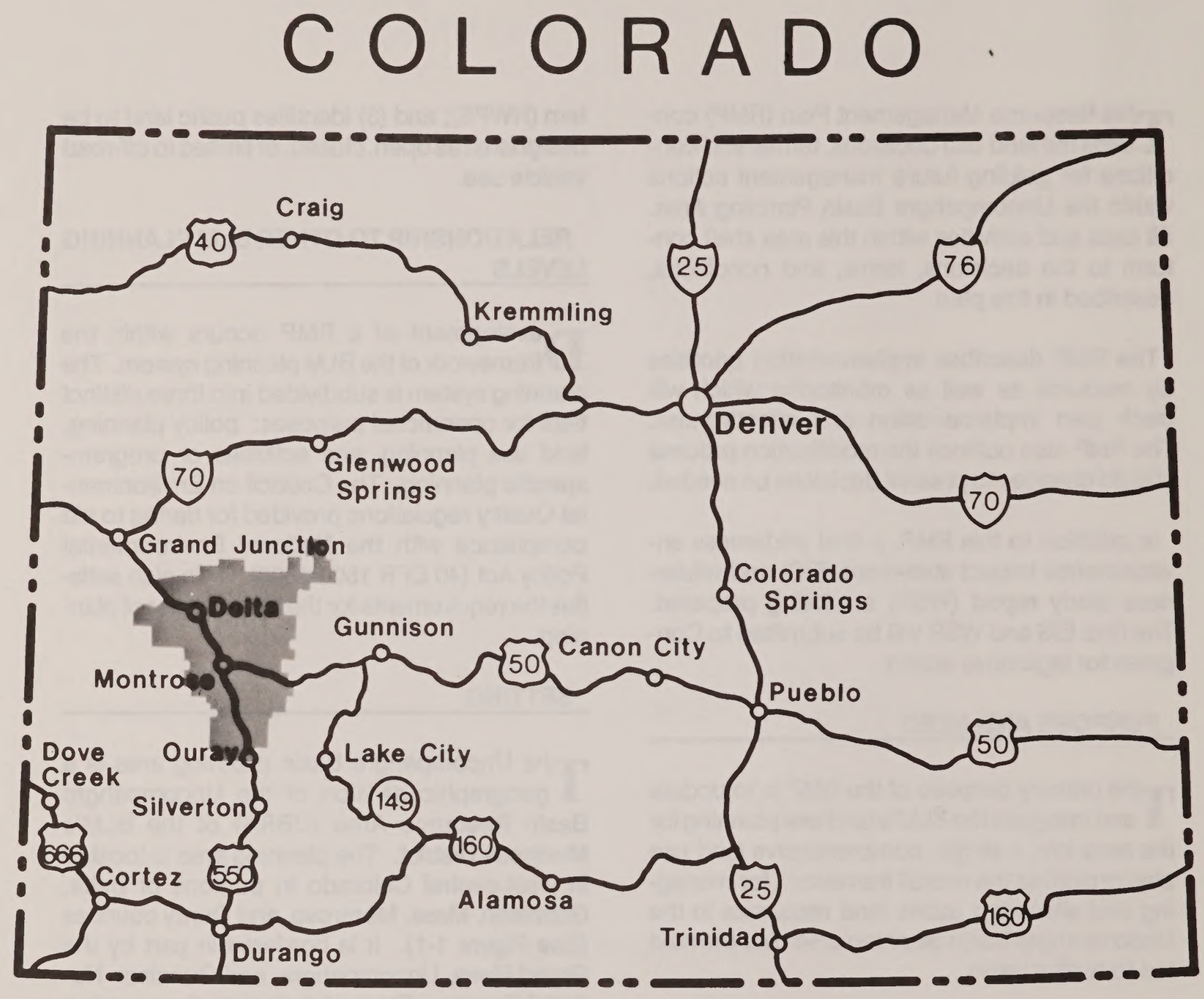

Figure 1-1 
Introduction

\section{Chapter One}

UNCOMPAHGRE BASIN PLANNING AREA

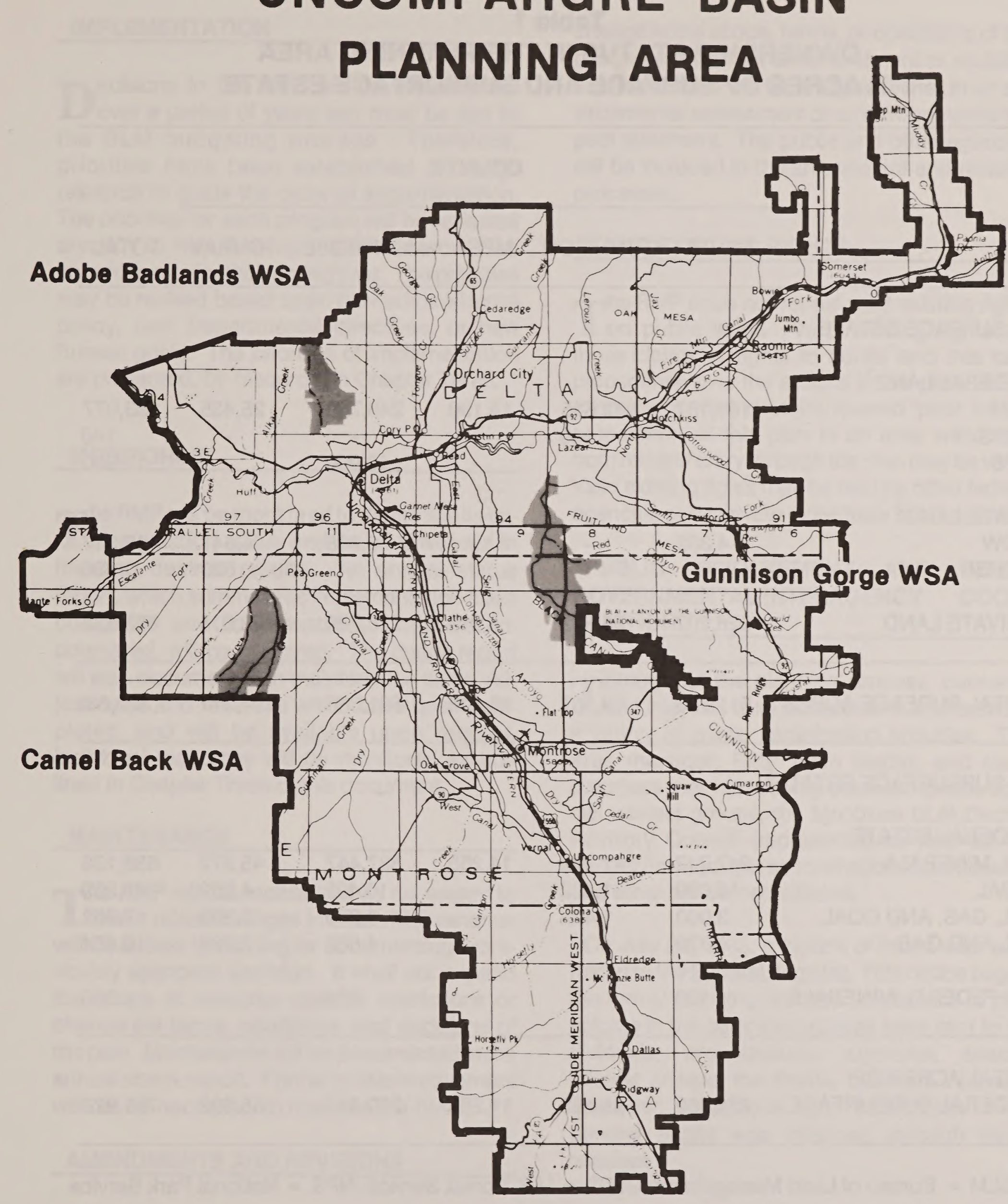

Wilderness Study Areas

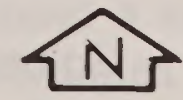

Figure 1-2

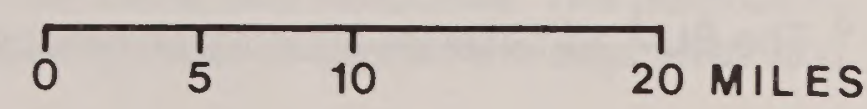




\section{Table 1 \\ OWNERSHIP STATUS IN THE PLANNING AREA IN ACRES OF SURFACE AND SUBSURFACE ESTATE}

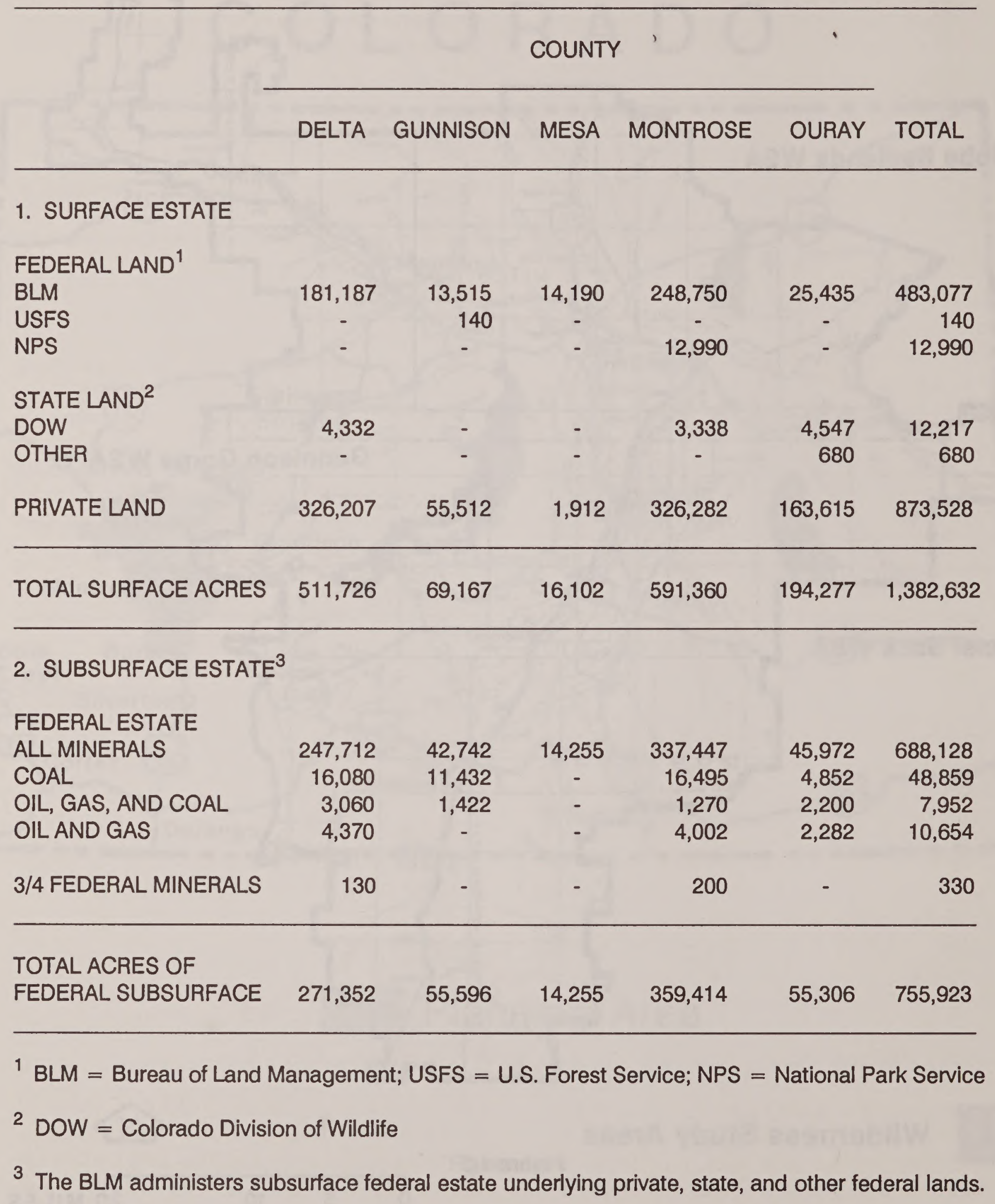




\section{IMPLEMENTATION}

$\mathbf{D}_{\mathrm{s}}^{\mathrm{e}}$ ecisions in the RMP will be implemented over a period of years and must be tied to the BLM budgeting process. Therefore, prlorities have been established for each resource to guide the order of implementation. The prloritles for each program will be reviewed annually to help develop the annual work plan commitments for the coming year. The priorities may be revised based upon new administrative pollcy, new Departmental directives, or new Bureau goals. The priorities of implementation are presented, by resource, in Chapter Three.

\section{MONITORING}

$\mathbf{T}$ he RMP will be monitored to determine its implementation status and its effectiveness in meeting desired results. An annual status report, which summarizes implementation tasks completed and implementation problems encountered, will be prepared. The status report will also document plan maintenance items, adjustments and revisions which have been completed, and will be available upon request. Individual resources will be monitored as outllned in Chapter Three of this document.

\section{MAINTENANCE}

$\mathbf{T}$ he RMP will be maintalned as necessary to reflect minor changes in data. Maintenance will be limited to refining or documenting a previously approved declsion. It shall not expand the scope of resource uses or restrictions or change the terms, conditions, and decisions of the plan. Malntenance will be documented in the annual status report. Formal public Involvement will not be necessary to maintain the RMP.

\section{AMENDMENTS AND REVISIONS}

$\mathbf{T}^{\mathrm{T}}$ he RMP may be amended or revised if major changes are necessary. Monltoring and evaluatlon findings, new data, new or revised policy, or a proposed action resulting In a change in the scope, terms, or conditions of the plan, would warrant an amendment or revision. An amendment will be analyzed either in an environmental assessment or an environmental impact statement. The public and other agencies will be included in the amendment and revision processes.

\section{VALID EXISTING RIGHTS}

$T$ he RMP does not repeal valid existing rights on public lands. Valid existing rights are those claims or rights to public land that take precedence over the actions in this plan. As an example, a mining claim located prior to the preparation of this plan in an area withdrawn from mineral entry through the plan may be valld. Valid existing rights may be held by other federal agencies or by private individuals or companies.

\section{PUBLIC INVOLVEMENT AND INTER- GOVERNMENTAL/INTERAGENCY COOR- DINATION}

$T^{\text {hroughout the planning process, concerns }}$ and interests of all publics were addressed in a variety of public participation activities. The area manager, RMP team leader, and team members met with county commissioners, speclal Interest groups, the Montrose BLM Dlstrict Advisory Council (representatives who advise the District Manager on local publlc land Issues), and other concerned citizens.

On July 28,1983 , a Notice of Intent was submitted to the Federal Register. This notice began the formal planning process. Invitations to participate in the planning process were sent to individuals, organizations, agencies, special interest groups, the media, business interests, academic institutions, and individuals. The general public was informed through news releases.

All publlcs were Invited to attend a serles of public scoping meetings held In August 1983 In Montrose, Delta, and Hotchkiss. The purpose of the meetings was to explain the objectives and 
goals of the RMP and identify resource management issues. Issue statements and comments were accepted from the public by mall and at the scoplng meetings. Land tenure adjustments, off-road vehicle use, and recreation, wilderness, and forestry issues recelved the most response.

The first RMP newsletter was published in March 1985 and mailed to about 700 addresses. A second newsletter was published and mailed in December 1985.

The public was invited to comment on three draft resource management alternatives (the Continuation of Current Management, Production, and Conservation alternatives) at a series of Open House Meetings held in Montrose, Delta, and Paonia in January 1986. Comments received were considered in finalizing these alternatives and in formulating the BLM's Preferred Alternative.

The draft RMP/EIS was filed with the Environmental Protection Agency in July of 1987.
Notice of availability of the draft and announcement of public hearings was published in the Federal Register on August 7, 1987; page 29445. The public was provided a 90-day comment period on the Draft RMP/EIS.

News releases also provided information concerning the Draft RMP/EIS and the public hearings which were held in Hotchkiss, Colorado, on September 22, 1987; in Lakewood, Colorado, On September 24, 1987; and in Montrose, Colorado, on September 29, 1987.

Fifty-one (51) persons testified at the public hearings. One hundred and seventy-three (173) persons, groups, or agencies submitted written comments. Both comments and responses were published in the Proposed RMP/Final EIS.

Notice of availability of the Proposed RMP/Final EIS was published in the Federal Register on OCtober 7, 1988; page 39538. This notice announced a 30 -day protest period. No protests were received. 


\section{Planning Issues and Associated Resource Decisions (All other resource decisions are identified in Chapter 2)}

\section{RESOURCE}

PLANNING ISSUE

RESOURCE DECISION

LANDS 1. identify lands suitable for disposal or lands that shouid be retained in pubilic ownership.

2. identify non-federal lands that would best serve public needs and interests if in public ownership.
A total of 143 tracts of public land totailing 11,026 acres are identified for further consideration for disposal. The remaining 472,050 will be retained inpubiic ownership.

If available, private lands may be acquired in Management Units 1, 2, 4, 7 , 9, 11 (see page 29 for acquisition criteria)

83,334 acres of Federal coal estate in the Paonia/Somerset Cimarron Ridge and Bookcilffs coal areas are identified as sultabie for further coal leasing consideration.
WATER QUALITY 4. Identify major source areas con(SALINITY) tributing to the salinity problem in the Colorado River drainage. Determine uses that contribute saiinity and deveiop measures to curtail the probiem.
Public lands totaling 26,547 acres wiil be intensively managed to reduce salinity loads in the Colorado River drainage.
FORESTRY
5. Identify those woodiands in the planning area which will be managed predominantly for either forage productlon or woodiand products.
Commercial forest on 3,127 acres and suitabie woodlands on 24,255 acres would be intensively managed for forest products. Seasonal restrictions would apply on 1,606 acres of commercial forest. 
6. Determine if development of the proposed Storm King Peak Ski areas would be compatible with wild life habitat, timber production, and coal production.
The Storm King Peak area will be managed to enhance its use as an elk calving area.
OFF-ROAD

VEHICLE USE
7. Considering resource values and current recreation activities and use, delineate ORV areas within the planning area with open or closed or limited designation. Identify any restrictions to be applled in areas recommended for limited use.
A total of 224,276 acres is open to ORV use and 38,600 acres is closed to ORV use. Vehicle use on 56,974 acres is limited to designated roads and trails yearlong and another 163,227 acres has seasonal limited designations.
8. Determine if any of the three WSAs, or portions thereof, should be recommended as suitable for inclusion in the National Wilderness Preservation System. Identify alternative management for those areas not recommended for wilderness designation.
Recommend the Gunnison Gorge WSA $(21,038$ acres) as suitable for wilderness designation. Recommend both the Camelback WSA $(10,402$ acres) and the Adobe Badlands WSA $(10,425$ acres) as non-suitable for wilderness designation.

Manage the Camelback area with emphasis on riparian/aquatic system management, wildlife habitat, and livestock grazing. Close the entire area to ORV use. Manage 6,783 acres of the Adobe Badlands WSA as an ONAVACEC to protect the scenic quallties and T\&E plants; and to reduce active erosion. Manage the remainder of the Adobe Badlands WSA ( 3,642 acres) as wiidlife habitat. 


\section{CHAPTER TWO}

\section{THE.UNCOMPAHGRE.BASIN RESOURCE.MANAGEMENT DECISIONS}

C hapter Two displays the land use decisions by Management Unit (A management unit is a geographically defined area which will be managed for a stated objective). It identifies the management objective for each unit and describes the management actions which will be allowed, limited, or excluded to meet the stated objective. It is the Proposed Plan as described in the Proposed RMP/Final EIS.

A map identifying the location or locations of each Management Unit is provided in the pocket inside the back cover. Crucial deer and elk winter range and bald eagle hunting habitat are identified on unpublished maps: located in the Uncompahgre Basin Resource Area Office.

\section{ASSUMPTIONS}

1. All actions will comply with current state and federal regulations; standards; and policies.

2. Site-specific activity plans will be developed or revised, if necessary, to provide detailed management guidance for all management units except the general resource management unit.

3. Site-specific Environmental Analyses (EAs) and Environmental Impact Statements (EISs), if required, will be developed for all management plans and projects within the planning area. Emphasis will be placed on analyzing plans and/or projects comprehensively for each management unit.

4. Lands cases generated by other agencies, individuals, and entities will be analyzed and processed on a case-by-case basis in accordance with guidance provided by this plan.
5. Recreation and Public Purposes Act (R\&PP) land use classifications currently under lease will be retained with the exception of the Delta County and Montrose County. landfills.

6. All Wilderness Study Areas (WSAs) will be managed to be consistent with the Wilderness Interim Management Policy until the final Congressional decision on wilderness designation or non-designation is made.

7. All areas designated as an Outstanding Natural Area (ONA) or a Research Natural Area (RNA) are also designated as Areas of Critical Environmental Concern (ACEC).

\section{STANDARD MANAGEMENT DIRECTION}

come resource management programs will Sbe standard throughout the planning area under the RMP: Unless changes in or additions to standard management directions are specifically. addressed in the management prescription for each management unit, these resources, programs, and activities will be managed as follows:

Air Quality. Activities and projects on public land will comply with applicable local, state, and federal air quality regulations. Mitigation to minimize air quality degradation will be incorporated into project proposals as appropriate.

Coal. Federal coal estate will be identified as acceptable for further leasing consideration.

Oil, Gas, and Geothermal Resources. Federal oil, gas, and geothermal estate on both federal surface and split-estatelands will be open to leasing with standard lease terms. Other con- 
ditlons for leasing such as no surface occupancy and seasonal stipulations (see Appendix A) are assigned in each management unit prescription; special stipulations and conditions also apply to federal surface and split-estate lands. Any speclal stlpulatlons (l.e., seasonal closures) prescribed for a management unit will also apply to seismic and drilling activities.

Resource Information for split-estate lands, upon which the recommended stipulations are based, has not been verified by the BLM. Verificatlon will occur durlng review of Applicatlons for Permit to Drill (APDs). On-site Inspectlon and consultation with the surface owner and operator may reveal that (1) the impacts addressed by the stipulation will be avoided or mitigated to an acceptable level, or (2) the resources of concern are not present. Upon either of these determinations by the Authorized Officer, the stipulations can be waived, modified, or excepted without public notice other than that provided for the APD. Consultation with the surface owner also requires the consideration of private uses of the surface. If, after on-site inspection and consultation, it is determined by the Authorized Officer that conditions necessary to avoid impacts to private resources would adversely impact the public resources addressed by these stipulations, the impacts will be assessed. If, based upon such assessment, the Authorized Officer makes a decision to substantially change or waive one or more stipulations, a 30-day public review period will be provided in addition to the public notice period for receipt of the APD. (These two 30-day notice and review periods may overlap.)

Locatable Minerals. All existing withdrawals that segregate federal mineral estate from location and entry under the general mining laws will be recommended for retention. Federal mineral estate in areas not under withdrawal will be open to entry and location.

Mineral Materials. Federal mineral estate will be open to disposal of mineral materials.
Soils and Water Resources. Water quality and erosion conditions will be inventoried and monitored. Measures designed to minimize erosion and water quality deterioration will be required in site specific plans for surface-disturbIng land use actlvitles. The area will be open to land treatments and development of in-channel structures and project facilities.

Riparian/Aquatic Systems. Riparian zones and aquatic habitats will be inventoried and monitored where necessary to provide informatlon to determlne proper management. Vegetatlon conditions and streambank cover will be maintained or improved. Measures designed to minimize site-speclflc riparian and aquatlc deterioration will be required in site specific plans for surface-disturbing land use activities.

Threatened and Endangered Species. Threatened and endangered species and unique plant associations will be inventoried and monitored where necessary to provide information to determine proper management. Clearances will be conducted on all proposed surface-disturbing activities and the U.S. Fish and Wildlife Service (USFWS) will be consulted as required. Measures designed to protect threatened and endangered species and their habitat will be required in all land use activity plans. Supplemental releases and reintroduction of federal and state listed endangered, threatened, and candidate species may be authorized following environmental analysis and consultation with the USFWS, the Colorado Division of Wildlife (DOW), and other affected partles.

Wild life Habitat. Wildlife forage allocations will remain at current levels until studies determine adjustments are needed to achieve management objectives. Additional forage allocations will be divided equally between wildlife and livestock grazing. Wildlife habitat monitoring studies will be established and/or maintained on all crucial winter ranges. The planning area will be open to land treatments and project facility development. Existing wildlife facilities and land 
treatments will be malntained. Supplemental releases and reintroduction of native or naturalized fish and wildlife species (excluding federal or state listed endangered, threatened, or candldate species) may be authorized by the District Manager following environmental analysis.

Livestock Grazing. Suitable public lands will be available for livestock grazing use. Livestock utilization will be managed at current forage allocation levels until studies Indicate adjustments are needed to achieve management objectives. New or additional available forage will be divided equally between livestock and wildlife. ExIsting Ilvestock facilitles will be maintained. Existlng allotment management plans (AMPs) will be updated as needed and new AMPs will be developed. New livestock facilities and land treatment projects will be developed if needed to achieve AMP objectives. Vegetation condition and trend monitoring studies will be established and/or maintained. Maximum sustained livestock utilization levels of key forage species will be 50 percent. Allotment categorization will determine management and monitoring intensity.

Forestry. Suitable commercial forest lands and plnyon-juniper woodlands will be managed for sustained yield production within the allowable cut restrictions determined by the Timber Production Capabilities Classification (TPCC) inventory.

Recreation. Public lands will be managed for extensive and diverse recreational use.

Off-Road Vehicles. Public lands will be open to off-road vehicle (ORV) use.

Cultural Resources. Cultural and historical sites will be inventoried. Clearances will be conducted on sites of all proposed surface-disturbIng activities. Measures designed to protect cultural and historical resources will be developed in consultation with the Advisory Council on Historic Preservation and the State
Historic Preservatlon Offlcer and will be requlred in all land use activity plans.

Paleontological Resources. Paleontological resources will be inventoried and appropriate protective measures will be developed if necessary.

Visual Resources. Public lands will be managed under current visual resource management (VRM) classifications and guidelines.

Major Utilities. Public lands will be open to development of major utility facilities. Stlpulations and mitigating measures will be developed on a case-by-case basis.

Powersite Withdrawals. Pending determination of potential, existing powersite withdrawals will be maintained. These lands will not be subject to further consideration for disposal. No significant long-term investments will be made on these lands unless the investment could be recovered prior to development.

Access. In addition to the specific access needs identified in the management unit prescriptions, the access needs identified in the resource area's transportation plan will be acquired as opportunities arise.

Fire Management. Any fire which occurs in a fire use category area before a prescribed burn plan is approved, or which is not within the limits of the prescription, or which threatens life or property will be suppressed as a conditional suppression area fire.

\section{DISPOSAL OF PUBLIC LANDS}

A total of 143 tracts of public land totalling A 11,026 acres have been identified for further consideration for disposal through sale or exchange under the RMP. 
Prlor to disposal, resources within identifled tracts will be managed according to the management prescription for the management unit in which they are located. Minlmal funds, if any, will be spent on improvements on these lands. Federal mineral estate will be conveyed with surface estate where it would be In the publlc interest.

Table 2

MANAGEMENT UNITS

\begin{tabular}{|c|c|c|c|}
\hline $\begin{array}{l}\text { MANAGEMENT } \\
\text { UNIT }\end{array}$ & $\begin{array}{l}\text { ACRES OF } \\
\text { PUBLIC } \\
\text { SURFACE }\end{array}$ & $\begin{array}{c}\text { PERCENTAGE } \\
\text { OF THE } \\
\text { PLANNING AREA }{ }^{1}\end{array}$ & $\begin{array}{l}\text { IMPORTANT RESOURCES, } \\
\text { VALUES, OR LAND USES }\end{array}$ \\
\hline 1 & 186,810 & $39 \%$ & $\begin{array}{l}\text { Livestock grazing, wildlife habitat, } \\
\text { recreation, woodlands }\end{array}$ \\
\hline 2 & 67,320 & $14 \%$ & Wildlife habitat, coal, woodlands \\
\hline 3 & 47,607 & $10 \%$ & $\begin{array}{l}\text { Woodlands, wildlife habitat, livestock } \\
\text { grazing }\end{array}$ \\
\hline 4 & 40,792 & $8 \%$ & Recreation, soils, woodlands \\
\hline 5 & 24,177 & $5 \%$ & Soils, recreation, oil and gas \\
\hline 6 & 21,038 & $4 \%$ & Wilderness, recreation, T\&E species \\
\hline 7 & 17,232 & $4 \%$ & Coal, wildlife habitat \\
\hline 8 & 8,942 & $2 \%$ & Recreation, soils \\
\hline 9 & 6,320 & $1 \%$ & $\begin{array}{l}\text { Riparian/aquatic habitat, livestock graz- } \\
\text { ing }\end{array}$ \\
\hline 10 & 3,292 & Less than $1 \%$ & $\begin{array}{l}\text { Wildlife habitat, coal, recreation, com- } \\
\text { mercial timber }\end{array}$ \\
\hline 11 & 1,990 & Less than $1 \%$ & Wildlife habitat, recreation \\
\hline 12 & 1,895 & Less than $1 \%$ & Recreation, T\&E species \\
\hline 13 & 377 & Less than $1 \%$ & T\&E species, soils \\
\hline 14 & 80 & Less than $1 \%$ & Recreation, scientific values \\
\hline 15 & 6,783 & $1 \%$ & T\&E species, scenic values, soils \\
\hline 16 & 48,422 & $10 \%$ & General land uses \\
\hline
\end{tabular}

${ }^{1}$ Percentages are rounded to whole numbers. 


\section{MANAGEMENT UNIT 1}

186,810 Acres of Pubilc Surface; 39 percent of the Planning Area

Management Unit 1 consists of 186,810 acres of pubilc land located primarily on the northeastfaclng slopes of the Uncompahgre Plateau north of Colorado Highway 90 . The area's range of elevations gives it a high value for both summer and winter livestock grazing.

Public iands within the management unit will be managed as " $\mathrm{i}$ " category (150,114 acres), "M" category (25,727 acres), and "C" category $(8,950$ acres) grazing allotments. Also, 2,019 acres that are presently unallotted for ilvestock use will be available for grazing application.

The management unit will be managed to improve vegetation conditions and forage avallability for livestock grazing. Land treatment projects and other facilitles designed to improve ilvestock forage and distribution will be developed. Intensive monitoring studies wiil be established and maintained on ail " $\mathrm{l}$ " and " $\mathrm{M}$ " category ailotments. Existing AMPs will be updated as needed and new AMPs will be developed for allotments without pians. As additional forage becomes available, livestock will have priority for allocation. Relinquished, cancelled, or acquired livestock grazing permits will be reissued according to reguiations.

Oil and Gas. Federal oil and gas estate will be open to leasing. Seasonal stipulations on seismlc and drilling activities will be in effect from December 1 through April 30 on 64,815 acres (federal surface) and 560 acres (split-estate) of crucial deer and elk winter range, and on 3,757 acres (federai surface) and 63 acres (spilt-estate) used by bald eagles for hunting habitat. Variances to this seasonal stipulation may be granted (see Appendix A).

Locatable Minerals. The Bureau of Reciamation (BOR) withdrawal on Fruitiand Mesa and both the BOR Dominguez withdrawai and the
BLM powersite classifications along the Gunnison River downstream of Delta will be recommended for revocation to allow for mineral exploration and development, facilitate resource management, and permit long-term land use planning.

Soils and Water Resources. Non-conflicting (does not conflict with the objective of the management unit) erosion controi objectives, projects, and mitigating measures will be incorporated into new and existing AMPs. In-channel structures and land treatment projects designed to reduce runoff and soil erosion will be developed.

Wildlife Habitat. Non-confilcting wildlife habitat management objectives, projects, and mitigating measures will be incorporated into new and existing AMPs. Existing wildlife habitat projects will be maintained. Bighorn sheep may be transplanted into the Winter Mesa area if they will not conflict with current and future livestock grazing forage allocations. Wiidlife will have first priority for all additional forage made available as a result of rangeland improvement projects designed to improve wildilife habitat funded by non-BLM sources.

Forestry. Woodiand harvest areas will be managed for increased forage production and will be compatibie with AMPs.

Recreation. River access will be developed at the Escaiante Bridge. Maps and informational materiais on river use will be provided. The BLM will manage recreation use In a manner that will minimize recreational Impacts on Interspersed and adjacent private land.

Off-Road Vehicles. A total of 7,240 acres in the Winter Mesa/Roubideau Creek area will be closed to ORV use. Vehicle use on cruclal deer and eik winter range $(64,815$ acres) will be limited to designated roads and trails from December 1 through April 30 if necessary to reduce stress on wintering deer and eik. The remainder of the management unit will be open to ORV use. 
Cultural Resources. A total of 5,848 acres of public land between Colorado Highway 90 and the Big Sandy Wash will undergo a Class III cultural inventory to determine the significance and location of high-value archeological sites. Upon completion of the inventory and data analysis, some of these sites may be assigned a special designation and a management plan may be developed.

Visual Resources. The management unit will be managed under VRM Class III guldellnes, except for Escalante Canyon which will be managed under VRM Class II guidelines to protect its scenic qualities.

Acquisition of Non-Federal Lands. If they are available, non-federal lands that would improve livestock management and increase crucial deer and elk winter range may be acquired.

Access. Public road access will be acquired into the Olathe Reservoir area for hunting and other recreatlonal purposes. Public trail access will be acquired on the McCarty Trail in lower Escalante Canyon to provide additional access into the Dominguez Canyon WSA.

Fire Management. A total of 97,543 acres of publlc land will be managed under the flre suppresslon category, wlth 8,657 acres Identifled for Intenslve suppresslon and 88,886 acres Identifled for conditlonal suppression. A total of 89,267 acres will be managed under the fire-use category where flre will be utillized as a management tool. Planned or natural ignitions meeting pre-determined prescriptlons will be allowed on these areas.

\section{MANAGEMENT UNIT 2}

67,320 Acres of Public Surface; 14 percent of the Planning Area

Management Unit 2 consists of 67,320 acres of public land located primarily on the southern end of the Uncompahgre Plateau and in the lower elevations of the North Fork Valley. These areas have large wintering deer and elk populatlons. Approximately half of the management unit is considered crucial deer and elk winter range. A portion of the unit, in the Camel Back/Roubideau Creek area, is suitable habitat for desert bighorn sheep.

The management unit will be managed to improve the areas' capabilities to support wintering deer, elk, and blghorn sheep populatlons. Land treatment projects and other facilities designed to improve the quality and quantity of winter habitat will be developed. Wildlife will have first priority for all additional forage made avallable as a result of BLM habitat improvement projects. All other land uses will be permitted if they will not degrade the areas' winter range capabilities. Disturbances will be minimized from December 1 through April 30 on crucial deer and elk winter range (37,007 acres). Habitat in the Camel Back/Roubideau Creek area will be available for possible introduction of desert bighorn sheep.

Coal. Federal coal estate will be open to leasing. Within crucial deer and elk winter range, seasonal stipulations on new road and facility construction may be necessary from December 1 through April 30 to reduce stress on wintering deer and elk.

Oil and Gas. Federal oil and gas estate will be open to leasing. Withln crucial deer and elk winter range $(37,007$ acres of federal surface and 8,850 acres of split-estate), seasonal stipulations on seismic and drilling activities will be in effect from December 1 through April 30 to reduce stress on wintering deer and elk. Variances to this seasonal stipulation may be granted (see Appendix A).

Mineral Materials. Federal mineral estate will be open to disposal of mineral materials. Within crucial deer and elk winter range, seasonal restrictions on disposal activities may be necessary from December 1 through April 30 to reduce stress on wintering deer and elk. 
Soils and Water Resources. Non-conflicting erosion control objectives, projects, and mitigation measures will be incorporated into new wildlife habitat management plans (HMPs). Land treatment and erosion control projects will be permitted if they are compatible with wildlife habitat management objectives.

Livestock Grazing. Livestock grazing will continue at current forage allocation levels and seasons of use unless studies determine adjustments are needed. Livestock will have first priority for all additional forage made available as a result of livestock operator-funded rangeland improvement projects. Non-conflicting Ilvestock management objectives, projects, and mitigating measures will be incorporated into new wildlife HMPs. Facility development and land treatment projects will be permitted if they would be compatible with wildlife habitat management objectives.

Forestry. The management unit will be available for woodland product harvests. On 37,007 acres of crucial deer and elk winter range, seasonal restrictions on harvest may be necessary from December 1 through April 30 to reduce stress on wintering deer and elk. Woodland harvest will be designed to increase forage production and will be compatible with wildlife habitat management objectives.

Off-Road Vehicles. A total of 2,482 acres in the Camel Back/upper Roubldeau Creek dralnage area will be closed to ORV use. Vehicle use in the remalnder of the management unit will be llmited to designated roads and trails from December 1 through Aprll 30. Varlances to this seasonal limitation may be granted if ORV use would not result in any negative impacts on wintering deer and elk.

Visual Resources. The management unit will be managed under VRM Class III guidelines.

Major Utilities. The management unit will be open to development of major utility facilitles. Within crucial deer and elk winter range, con- struction activities may be restricted from December 1 through April 30 if necessary to reduce stress on wintering deer and elk.

Acquisition of Non-Federal Lands. If they are available, non-federal lands that are necessary for effective management of crucial deer and elk winter range ay be acquired.

Access. Public access will be acquired into the McDonald Mesa, Roatcap-Jay Creek, Spaulding Peak/Dry Creek, Oak Mesa, and Oak Ridge areas for hunting and other recreational uses, wildlife habitat management, and timber and woodlands management.

Fire Management. A total of 53,502 acres of public surface will be managed under the fire suppression category, with 48,118 acres identified for intensive suppression and 5,384 acres identified for conditional suppression. A total of 13,818 acres will be managed under the fire-use category where fire will be utilized as a management tool. Planned or natural ignitions meeting pre-determined prescriptions will be allowed in these areas.

\section{MANAGEMENT UNIT 3}

47,607 Acres of Public Surface; 10 percent of the Planning Area

Management Unit 3 consists of 47,607 acres of public land located primarily on the northeastfacing slopes of the Uncompahgre Plateau. The management unit contains some of the most productive pinyon-juniper woodland sites In the planning area which are used extensively for Ilvestock grazing and are valuable deer and elk habitat.

The management unit will be managed for sustalned yleld production of the woodland resource within the allowable cut restrictions determined by the TPCC inventory $(23,206$ acres). 
Oil and Gas. Federal oil and gas estate will be open to leasing. A seasonal stipulation on seismic and drilling activitles will be in effect on cruclal deer and elk winter range $(28,552$ acres of federal surface and 25 acres of split-estate) from December 1 through Aprll 30 if necessary to reduce stress on wintering deer and elk. Varlances to thls seasonal stipulation may be granted (see Appendix A).

Soils and Water Resources. Non-confllcting erosion control objectives, projects, and mitlgatIng measures will be incorporated Into new forest management plans (FMPs). Exlstlng erosion control projects will be maintalned and new projects developed if they will not decrease the woodland base.

Wildlife Habitat. Non-conflicting wildlife habitat management objectives, projects, and mitigating measures will be incorporated into new FMPs. Existing wildlife habitat projects will be malntalned and new projects developed if they will not decrease the woodland base.

Livestock Grazing. Non-conflicting livestock grazing management objectives, projects, and mitlgating measures will be incorporated into new FMPs. Existing livestock projects will be maintained and new projects developed if they will not decrease the woodland base.

Off-Road Vehicles. The management unit will be open to ORV use except In cruclal deer and elk winter range $(28,552$ acres) where vehlcle use will be llmited to designated roads and trails from December 1 through April 30 if necessary to reduce stress on wintering deer and elk. Use of ORVs for woodland management and harvest purposes will be authorized year-round.

Access. Public access will be acquired into the Beaver Hill and Linscott Canyon areas for woodland harvest and recreation purposes.

Fire Management. A total of 25,162 acres of public land will be managed under the fire suppresslon category, with 21,187 acres identified for intensive suppression and 3,975 acres identified for conditional suppression. A total of 22,445 acres will be managed under the fire-use category where fire will be utilized as a management tool. Planned or natural ignitlons meeting pre-determlned prescriptlons will be allowed on these areas.

\section{MANAGEMENT UNIT 4}

40,792 Acres of Public Surface; 8 percent of the Planning Area

Management Unit 4 consists of the 40,792 acres of public lands surrounding the Gunnison Gorge. The management unlt is characterlzed by a diversity of landscapes and high-value recreation opportunities. The need to protect both the quality and diversity of recreatlon opportunities and to facilitate recreation use will be recognized as important during the formulation of management decisions affecting the area.

The management unit will be managed as the Gunnison Gorge Special Recreation Management Area (SRMA). Maps, interpretive materials, and facilities will be developed. Recreation use will be monitored and possibly restricted as necessary to protect natural features and recreation opportunities.

Lands In the Peach Valley area (15,610 acres) wlll be managed for ORV recreatlon opportunities. A minimum of restrictlons would be placed on surface-disturbing activities and a high concentration of recreation users will be permitted within this area.

Motorized access to the remainder of the management unit $(25,182$ acres) will be limited to designated road and trails, the majority of whlch are primitive in character. This area will be managed to maintaln a predominantly natural environment with low but evident human concentrations and impacts. 
Oil and Gas. Federal oil and gas estate will be open to leasing. A seasonal stipulation on seismlc and drilling activities will be in effect from December 1 through April 30 on crucial deer and elk winter range $(8,077$ acres of federal surface and 280 acres of split-estate). Variances in this seasonal restriction may be granted (see Appen$\operatorname{dix} A$ ).

Locatable Minerals. Federal mineral estate will be open to entry and location. The BLM protective withdrawal (PLO 5261; September 15, 1972) will be revoked and the BOR withdrawal on Fruitland Mesa will be recommended for revocation. Revoking these mineral withdrawals will allow for mineral exploration and development, facilitate resource management, and permit long-term land use planning.

Soils and Water Resources. The Elephant Skin Wash salinity control project will be maintained to reduce saline runoff. Elephant Skin Wash will be protected from surface-disturbing activities.

Wildlife Habitat. Bighorn sheep habitat in the Smith Fork Canyon (2,250 acres) will be monitored and protected. Activities and land uses that are consistent with maintaining the necessary forage and isolated habitat requirements of bighorn sheep will be permitted.

Livestock Grazing. Livestock arazing will continue at current forage allocation levels and seasons of use unless studies indicate that adjustments are needed. The 140-acre Gunnison Forks habitat management area will remain unallotted for livestock grazing. Livestock forage utilization will be limited to 35 percent in the Elephant Skin Wash area (2,370 acres) if necessary to protect soils by maintaining an optimum basal ground cover.

Forestry. A 1,255-acre portion (in the Black Ridge area) of the 2,500 acres of harvestable woodlands within the management unit will be available for harvest. This area will be closed to harvest from December 1 through April 30 to protect crucial deer and elk winter range. The remaining harvestable woodlands ( 1,245 acres) will be closed to harvest.

Off-Road Vehicles. A total of 15,610 acres In the Peach Valley area will be open to ORV use. To protect natural and scenic values, vehicle use in the Elephant Skin Wash area and the remainder of the management unit will be limited to designated roads and trails yearlong.

Visual Resources. The 15,610 acres open to ORV use will be managed under VRM Class IV guidelines.

Major Utilities. A total of 2,462 acres in the Smiths Mountain and Gunnison Forks areas will be open to but not preferred for development of new major utility facilities. These lands may be utilized for major utility development if there are no feasible alternatives. The remainder of the management unit will be closed to new major utility development to protect natural and scenic values.

Acquisition of non-Federal lands. Actions will be initiated to acquire 2,200 acres of nonfederal lands as identified in the Gunnison Gorge Recreation Area Management Plan (RAMP), that are necessary to facilitate public access and enhance recreational values.

Access. Public access will be acquired along the Gunnison Gorge rim southwest of the Gunnison Forks and from Colorado Highway 92 to the Gunnison River in the Austin area for recreation purposes.

Fire Management. A total of 26,070 acres of public land will be managed under the fire suppression category and identified as conditional suppression areas. A total of 14,722 acres will be managed under the fire-use category where fire will be utilized as a management tool. Planned or natural ignitions meeting pre-determined prescriptions will be allowed on these areas. 


\section{MANAGEMENT UNIT 5}

24,177 Acres of Public Surface; 5 percent of the Planning Area

Management Unit 5, totalling 24,177 acres, consists of Mancos shale hills commonly known as the "adobes". These highly erodlble soils, combined with a lack of protective vegetation, can produce sediment loads in local watersheds that are high in salinity. High precipitation runoff rates from the adobes contribute to overall salinity levels in the Upper Colorado River Basin. Sallnity ylelds are Increased within locallzed areas due to Increased eroslon from surface dlsturbing activitles Including ORV use and Ilvestock grazlng.
The management unit will be managed to reduce salinity loads In the Upper Colorado Rlver Basin. In-channel structures and land treatment projects designed to reduce runoff, erosion, and sedimentation will be developed, and surface protection measures will be implemented. Forage utilization will be managed to achleve the basal ground cover objectlves identifled in Table 3. Surface-dlsturbing activitles will be curtailed from March 1 through May 31 when saturated soils are most vulnerable to damage. Activitles and other land uses which are consistent with maintalning the soil and vegetative conditions necessary to reduce erosion and salt contributions to the river basin will be permitted.

Table 3

\section{OBJECTIVES FOR PERCENT GROUND COVER WITHIN MANAGEMENT UNIT 5}

\begin{tabular}{|c|c|}
\hline RANGE SITE & LOCATION \\
\hline
\end{tabular}

\begin{tabular}{lcr}
\hline Stony saltdesert & North of Delta & 10 \\
Clayey saltdesert & South of Hotchkiss & 10 \\
Salt flats & South of Hotchkiss & 7 \\
Clayey saltdesert & Bone Mesa & 10
\end{tabular}

Oil and Gas. Federal oil and gas estate will be open to leasing. A seasonal stipulation on seismic and drilling activities will be in effect from March 1 through May 31 to protect erodible and saline soils on 24,177 acres of federal surface and 4,155 acres of split-estate. Varlances to this seasonal stipulation may be granted (see Appen$\operatorname{dix} A$ ).

Mineral Materials. Federal mineral estate will be open to mineral material activities except from March 1 through May 31 if necessary to protect wet soils.

Livestock Grazing. Livestock grazing will be allowed except from March 20 to range readiness to protect plant species during the spring growth period, and to prevent soil disturbance when saturated soils are most vulnerable to damage. If the basal ground cover is less than the objectives identified in Table 3 livestock forage utilization will be managed at 35 percent of key forage species to increase basal ground cover.

Off-Road Vehicles. To protect highly saline soils, vehicle use in the entire management unit will be limited to designated roads and trails yearlong.

Major Utilities. The management unit will be open to development of major utility facilities but no surface-disturbing activities will be permitted 
from March 1 through May 31 if necessary to protect wet soils.

Fire Management. A total of 22,992 acres of public land will be managed under the fire suppression category and Identified as conditional suppression areas. A total of 1,185 acres will be managed under the flre-use category where fire will be utillzed as a management tool. Planned or natural lgnitlons meeting pre-determlned prescrlptlons will be allowed on these areas.

\section{MANAGEMENT UNIT 6}

21,038 Acres of Public Surface; 4 percent of the Planning Area

Management Unit 6 is the Gunnison Gorge WSA (CO-030-388). The WSA, totalling 21,038 acres, will be recommended as preliminarily suitable for wilderness designation. Until a final Congressional decision on wilderness designatlon or non-designation Is made, the Gunnison Gorge WSA will be managed according to the Wilderness Interim Management Policy and the Gunnison Gorge RAMP.

Durlng the wilderness intensive inventory, the Gunnlson Gorge was determined to meet the wilderness size requirement of at least 5,000 acres, to be natural, and to provide outstanding opportunlties for solitude and primitive/unconflned recreation. The scenic and wilderness canyon complex of the area has received considerable publicity and public interest. If designated as wilderness by Congress, activities and land uses that are consistent with preserving the natural condition and wilderness character of the area would be permitted.

Air Quality. The management unit would be managed within federal air quality Class II guidelines unless the State of Colorado reclasslfles the area, or other areas, as a result of procedures prescribed In the Clean Air Act as amended in 1977. Under other state authorities, the Gunnlson Gorge WSA is currently managed as a Category I area where more restrictlve sulfur dloxide requirements apply.

Oil and Gas. Federal oll and gas estate would be closed to future leasing. There are no preFLPMA leases in the WSA. Development of any post-FLPMA leases in would be permitted only if activities would result in no impairment of wilderness characteristics.

Locatable Minerais. The management unit would be closed to mineral entry and locatlon except for pre-FLPMA clalms determined to have valld discoveries. The majority of the area (74 percent) is presently withdrawn from mineral entry.

Mineral Materials. The management unit would be closed to disposal of mineral materials.

Soils and Water Resources. Where natural recovery is unlikely, deteriorated watershed conditions would be restored if life, property, or wilderness values are threatened, or if serious depreciation of important environmental qualities outside the wilderness area is evident. Revegetation efforts would be limited to use of native or naturalized species. Whenever feasible, non-motorized access and project development methods would be required. Approval of the BLM Director would be required for all watershed restoration projects.

Threatened and Endangered Species. Threatened and endangered species research and habitat improvement would be permitted if activities are consistent with protection of wilderness values. Habitat would be managed for federally-listed bald eagles and peregrine falcons and state-listed river otters. Recreation use would be restricted if necessary for the protection of threatened and endangered species.

Wildlife Habitat. Wildlife habitat would be managed to allow for natural distribution, numbers, and interaction of indigenous wildlife and fish species. Developed facilities, if necessary for the continued existence or welfare of a wildlife 
species, would be permissible if wilderness characteristics would not be impaired. Bighorn sheep habitat and deer and elk winter range would be managed in cooperation with the Colorado DOW. Supplemental releases of blghorn sheep would be permitted as identified in the 1986 reintroduction plan or its future amendments.

Livestock Grazing. Livestock grazing and facility maintenance would be managed at levels and conditions established prior to wilderness designation. New rangeland improvements would be permissible if determined to be necessary for rangeland and/or wilderness protection.

Forestry. Woodland harvest and/or management would be permitted only for control of insects and disease if determined necessary to protect resources outside the management unit. There is a total of 337 acres of productive woodlands within the WSA that would be unavailable for harvest.

Recreation. Recreation use would be regulated as necessary to protect wilderness values. Highest priority would be given to low-impact recreation activities that could not be accommodated outside the wilderness environment. Opportunities for non-motorized recreation in a predominantly natural environment would be maintained. Facilities, improvements, and signs would be limited to those necessary to protect wilderness resources along with public health and safety. Permits would be required for all commercial recreation uses and, if necessary to protect wilderness values, for all non-commercial recreationists. Hunting, fishing, and recreational trapping would be permitted.

The river corridor would be managed to maintain very low human group concentrations and little overall evidence of human use. River-boating use would be limited to six to ten group encounters per day with no more than two (as per the 1988 Gunnison Gorge RAMP) commerciallyoutfitted trip allowed per day. Allocations between private and commercial river-boating use would be made if necessary to protect wilderness values or to emphasize opportunities for specific recreational experiences such as selfreliance as opposed to guided and outfitted experiences.

Off-Road Vehicles. Vehicle use in general would be eliminated from the management unit. Vehicle use would be permitted in certain circumstances involving valid existing rights, livestock grazing, fire suppression, life-threatening emergencies, and wilderness area administration. The rugged canyon area has few vehicular access routes.

Cultural and Paleontological Resources. In most instances, cultural and paleontological resources would be subject to the forces of nature in the same manner as other wilderness resources. Study or management would not entail excavation, stabilization, or interpretation. Exceptions may be granted by the BLM State Director for unusually significant cultural or paleontological resources.

Visual Resources. The management unit would be managed under VRM Class I guidelines.

Major Utilities. The management unit would be closed to development of utility facilities. The area is not within the lands identified as needed for future major utility development in the 1980 and 1985 Western Regional Utility Corridor Study(s).

Hydroelectric Development. Several hydroelectric projects have been proposed for development on the Gunnison River which would be within or affect the WSA. Protective withdrawals have restricted major on-theground evaluations by the proponents. The existing powersite reserves and BOR withdrawals affecting the Gunnison Gorge would be recommended for revocation. However, the final determination on the status of these withdrawals will be made by the President and Congress. 
Access. Public access to the WSA boundary in the Red Canyon area would be identified for acquisition.

Agricultural Development. No agricultural or related development would be permitted within the management unit. The BLM would recommend revocation of the portion of the BOR Fruitland Mesa withdrawal that is within the WSA.

Fire Management. A total of 21,038 acres would be managed under the fire-use category where fire would be utilized as a management tool. Only natural Ignitions meeting pre-determined prescriptions would be allowed in this area.

\section{MANAGEMENT UNIT 7}

17,232 Acres of Public Surface; 4 percent of the Planning Area

Management Unit 7 consists of 54,474 acres of federal coal estate within the planning area and 1,756 acres of federal coal estate outside of the planning area. A 17,232-acre portion of this federal coal estate underlies federal surface estate.

The management unit will be managed for both existing and potential coal development. Development of existing coal leases will continue, and unleased federal coal will be identified as acceptable for further coal leasing consideration with a minimum of multiple-use restrictions. Activities and land uses that are consistent with maintaining existing coal operations and the potential for coal development will be permitted.

Oil and Gas. Federal oll and gas estate will be open to leasing. A seasonal stipulation on seismic and drilling activities will be in effect from December 1 through April 30 on 1,730 acres (federal surface) of crucial deer and elk winter range, and on 1,637 acres of federal surface and 630 acres of split-estate lands used as hunting habitat by bald eagles. Variances in these seasonal stipulations may be granted (see Appendix A).

Riparian/Aquatic Systems. Riparian/aquatic zones up to one-quarter mile wide will be protected. Activities that disturb these areas could be approved on a site-specific basis after consultation with affected entities and development of mitigating measures.

Wildlife Habitat. Wildlife will have priority for forage allocations on crucial deer and elk winter range $(1,730$ acres).

Forestry. All commercial forest lands and pinyon-juniper woodlands that are suitable for harvest will be managed for sustained yield production within allowable cut restrictions determined by the TPCC inventory.

Off-Road Vehicles. Vehicle use in the riparian zones associated with Bear and Roatcap creeks will be limited to designated roads and trails yearlong. Vehicle use in crucial deer and elk winter range $(1,730$ acres) will be limited to designated roads and trails from December 1 through April 30 if necessary to reduce stress on wintering deer and elk.

Major Utilities. Corridors one-quarter mile wide and located on each side of Colorado Highway 133 will be open to development of major utility facilities. The remainder of the area would be closed to major utility facilities except for those needed for coal development. This management would greatly reduce the longterm conflicts between new utility facilities and the potential surface effects of coal mine subsidence.

Acquisition of Non-Federal Lands. If they are available, non-federal lands that are necessary for effective management of riparian zones along with crucial deer and elk winter range may be acquired.

Fire Management. A total of 14,910 acres of public land will be managed under the fire sup- 
pression category and Identified as Intensive suppression areas. A total of 2,322 acres will be managed under the fire-use category where fire would be utillzed as a management tool. Planned or natural ignitions meeting pre-determined prescriptions will be allowed on this area.

\section{MANAGEMENT UNIT 8}

8,942 Acres of Publlc Surface; 2 percent of the Planning Area

Management Unit 8 is 8,942 acres of publlc land northeast of Delta that consists of Mancos shale (adobe badlands) hills with little vegetative cover. The area is suitable and utilized for ORV recreation. ORV activities typically involve local residents and occur during the spring, fall, and winter.

The management unit will be managed as open to ORV use. Recreational and competitive ORV use and a high concentration of recreation users will be permitted within the management unit. Facilities such as informational signs and motorcycle loading ramps may be developed if constructed and maintained to BLM standards by local ORV organizations. A minimum of restrictions will be placed on surface-disturbing activities that do not impede or endanger ORV recreationists.

Prlor to management of the area for ORV use, an Inventory will be conducted to identify threatened and endangered plant populations. The management unit's proposed boundary will be adjusted to exclude threatened and endangered plants. If plants or plant communities cannot be excluded from the management unit, protective fencing or other measures will be implemented to protect the plants. The USFWS will be consulted.

Livestock Grazing. Grazing use will continue In the management unit but construction of facilities, such as livestock control fences, that create safety hazards or impede free vehicle use will not be permitted.

Visual Resources. The management unit will be managed under VRM Class IV guidelines.

Major Utilities. The management unit will be open to development of major utility facilitles.

Fire Management. A total of 8,942 acres of public land will be managed under the fire suppression category and identified as conditional suppression areas.

\section{MANAGEMENT UNIT 9}

6,320 Acres of Public Surface; 1 percent of the the Planning Area

The public land riparian zones that comprise Management Unit 9 occur throughout the planning area and are generally associated with perennial or intermittent streams. These areas $(6,320$ acres) have a very high productive capability and are very important in maintalning the water quality of the adjacent streams.

The management unit will be managed to restore and enhance riparlan vegetation along 40 miles of streams. Objectives and projects designed to accelerate Improvement of specles diversity, streambank cover and stability, and instream structure, and to raise the water table will be incorporated Into existing activity plans or developed in new riparian/aquatic system management plans. All areas will be intensively monitored for vegetation, aquatic habitat, and erosion conditions.

Coal. Coal development will be considered on a site-specific basis after consultation with affected entities and formulation of mitigating measures.

Mineral Materials. Federal mineral estate will be closed to disposal of mineral materials except 
for saies which would result in negiigibie or no impacts to the riparian and aquatic systems.

Solls and Water Resources. Non-conflleting eroslon control and water quality improvement objectlves and projects wiii be incorporated into new riparian/aquatic system management plans.

Wildlife Habitat. Non-conflicting wildlife habitat management objectives, projects, and mitigating measures will be incorporated into new rlparian/aquatic system management pians.

Livestock Grazing. Livestock grazing use wili be permitted in riparian zones except from March 1 through range readiness, during which time it would be eliminated to accelerate Improvement of riparian vegetation. To improve the condition of riparian zones, management practices and principles will be estabilished in activity plans. Utilization of 35 percent by weight of key forage species will be used as a general guidance for improvement; this may vary depending on the individual riparlan system. Trailing use wili be limited as much as possible and conflned to establlshed roads. Trailing livestock will not be permitted to bed in riparian zones uniess absolutely necessary.

Forestry. Woodland product harvests wili not be permitted in the management unit.

Off-Road Vehicles. A total of 680 acres in Roubideau and Potter creeks will be ciosed to ORV use. Vehicle use in the remainder of the management unit will be limited to designated roads and trails yearlong.

Major Utilities. The management unit will be open to development of major utility facilities. Surface-disturbing activities which wouid have long-term adverse effects on riparian/aquatic systems will be prohiblted.

Acquisition of Non-Federal Lands. If they are avallable, non-federal lands that are necessary for effective management of riparian/aquatic systems may be acquired.
Access. Pubiic access will be acquired into the Terror Creek area for project development and recreation purposes. The Potter Creek road (five miles) and the Dry Fork of Escalante Creek road (two miles) will be closed and rehabllitated and removed from the transportation plan.

Fire Management. A totai of 3,082 acres of public land will be managed under the fire suppression category, with 1,607 acres identified for intensive suppression and 1,475 acres identified for conditional suppression. A total of 3,238 acres wiil be managed under the fire-use category where fire wiii be utilized as a management tool. Pianned or natural ignitions meeting pre-determined prescriptions will be aliowed on these areas.

\section{MANAGEMENT UNIT 10}

3,292 Acres of Public Surface; less than 1 percent of the Planning Area

Management Unit 10 consists of two tracts in the High Park/Storm King Peak area 20 miles southeast of Montrose. The management unit $(3,292$ acres of pubiic land) ranges from 8,500 feet to over 10,000 feet in elevation, and is used extensively as an elk caiving area in the spring. The largest commercial timber stands In the planning area exist in this unit.

The management unit will be managed to enhance its use as an elk calving area. Any disturbance during the calving season (May 1 through June 15) will be limited as much as possible. Habitat in eik calving areas wiil be improved, and wildife wiil have first priority for allocation of new forage.

Oil and Gas. Federal oil and gas estate $(3,292$ acres of federal surface and 1,423 acres of splitestate lands) will be open to leasing with a seasonai stipuiation on seismic and drilling activities in effect from May 1 through June 15 to prevent disturbance of calving elk. Variances to 
thls seasonal stlpulation may be granted (see Appendix A).

Solls and Water Resources. Stipulations designed to malntain soil stability and prevent soil slumplng will be incorporated into plans for all surface-dlsturbling land use activities.

Forestry. Skid trails and other roads will be closed and rehabilitated; main haul roads will remaln avallable for public use.

Off-Road Vehicles. The management unit will be open to ORV use except during the elk calvIng season when all roads will be closed. Access for maintenance of the existing communications site will be permitted at all times.

Major Utilities. Publlc lands will be open to development of major utility facilities but no surface-dlsturblng activitles will be permitted durlng the elk calving season.

Acquisition of Non-Federal Lands. If they are available, non-federal lands that would expand elk calving areas and Improve extensive recreational opportunitles may be acquired.

Access. Public access will be acquired Into the Storm King and High Park areas for timber harvest and extensive recreation purposes.

Fire Management. A total of 3,292 acres of public land will be managed under the fire suppression category and identified as intensive suppression areas.

\section{MANAGEMENT UNIT 11}

1,990 Acres of Publlc Surface; less than 1 percent of the Planning Area

Management Unit 11 is comprised of 1,990 acres of public land adjacent to the Gunnison River west of Delta. It adjoins the Escalante State Wildlife Area which is administered by the Colorado DOW. The management unit present-
Iy recelves considerable use by waterfowl as nesting and resting habitat. Additional management and minor developments could enhance its potentlal for increased use as waterfowl habitat.

The management unit will be managed as waterfowl habltat. Adequate cover, wetlands, and nesting structures will be provlded. Disturbance will be minimlzed during the breeding and nesting season (March 15 through June 30). Activities and land uses that are consistent with maintaining waterfowl habitat characteristics will be permitted. The BLM will coordinate management of the area with the DOW.

Oil and Gas. Federal oil and gas estate $(1,990$ acres of federal surface and 150 acres of splitestate lands) will be open to leasing with seasonal stlpulations on seismlc and drllling activities in effect from March 15 through June 30 to protect waterfowl habltat, and from December 1 through April 30 on habitat used for hunting by bald eagles. Variances to the seasonal stipulatlons may be granted (see Appendix A).

Locatable Minerals. The BOR withdrawal and the BLM powersite classifications in this management unit will be recommended for revocation and opening to permit mineral exploration and development, facilitate resource management, and permit long-term land use planning. Federal mineral estate will be opened to entry and location.

Mineral Materials. Federal mineral estate will be open to disposal of mineral materials except during the waterfowl nesting season.

Acquisition of Non-Federal Lands. If they area available, non-federal lands that are necessary to Increase waterfowl habitat and facilitate development and management of the area may be acquired.

Fire Management. The entire management unit $(1,990$ acres $)$ will be managed under the fire suppression category and identified as a conditional suppression area. 


\section{MANAGEMENT UNIT 12}

1,895 Acres of Public Surface; less than 1 percent of the Planning Area

Management Unit 12 is 1,895 acres of public land In Escalante Canyon approximately six miles southwest of the Gunnison River. Several listed plant species and two unique plant assoclatlons occur In the management unit. The area also receives signiflcant recreational use due to its scenlc qualities and the presence of eroded potholes In Escalante Creek.

The management unit is designated as the Escalante Canyon Area of Critical Environmental Concern (ACEC). Thls designatlon will enhance management and protection of the listed plant species and unique plant associations, and will improve the publlc's awareness of the recreational hazards of the Escalante potholes. Plan monitoring studies will be developed and activitles designed to Improve these plants' habitat conditions will be initiated. Surface-disturbing activitles will be restricted. Informatlonal signs Identifying potential recreational hazards will be provided. Camping will be limited to designated areas.

Oil and Gas. Federal oil and gas estate will remain open to leasing with a no surface occupancy stipulation.

Locatable Minerals. The management unit will be withdrawn from entry and location for locatable minerals.

Mineral Materials. The management unit will be closed to disposal of mineral materials to protect the potential habitats of listed species and unlque plant associations.

Livestock Grazing. Livestock grazing will continue at current levels unless studies determine threatened and endangered plant species and unlque plant associations or their potential habltats are being degraded.
Forestry. To prevent accidental destruction of Ilsted specles and unlque plant assoclations, woodland harvests will not be permitted.

Off-Road Vehicles. To prevent accidental destruction of listed species and unique plant associations, vehicle use within the management unit will be limited to designated roads and trails yearlong.

Visual Resources. The management unit will be managed under VRM Class II guidellnes to maintain its scenlc qualities.

Major Utilities. The management unit will be closed to development of major utilities to prevent accidental destruction of listed species and unique plant associations, and to maintain its scenic qualities.

Fire Management. All 1,895 acres of public surface in the management unit will be managed under the fire-use category where fire will be utilized as a management tool. Planned or natural ignitions meeting pre-determined prescriptions will be allowed.

\section{MANAGEMENT UNIT 13}

377 Acres of Public Surface; less than 1 percent of the Planning Area

Management Unit 13 consists of two tracts totalling 377 acres of public land eight miles east of Montrose. The smaller tract is north of Highway 50 and the larger tract is south of the highway. The tracts contain the largest population of the endangered clay-loving wild buckwheat in the planning area and also have significant populations of Montrose penstemon, a candidate species.

The entire management unit is designated as the Fairview Research Natural Area/Area of Critical Environmental Concern (RNA/ACEC). Plant monitoring studies will be developed in cooperation with the Colorado Natural Areas Program 
and actions designed to improve habitat conditions will be initiated. Surface-disturbing activities will be restricted to protect the threatened and endangered species and their potential habitat.

Oil and Gas. Federal oil and gas estate will remain open to leasing with a no surface occupancy stipulation.

Locatable Minerals. The management unit will be withdrawn from entry and location for locatable minerals.

Mineral Materials. The management unit will be closed to disposal of mineral materlals to prevent accidental destruction of threatened or endangered plant specles or their potential habitat.

Livestock Grazing. Livestock grazing will continue at current levels unless studies determine threatened and endangered plant species or their potential habitats are being degraded.

Off-Road Vehicles. To prevent accidental destruction of threatened or endangered plant species or their potential habitat, the management unit will be closed to ORV use.

Major Utilities. The management unit will be open to development of major utillity facllities, except plpelines, so long as there will be no dlsturbance of threatened or endangered plant specles or their potentlal habitat.

Fire Management. The management unit (377 acres) will be managed under the fire suppresslon category and identified for conditional suppresslon.

\section{MANAGEMENT UNIT 14}

80 Acres of Public Surface; less than 1 percent of the Planning Area
Management Unit 14 is an 80 -acres site consisting mainly of a volcanic structure with highvalue scientific, interpretive, and scenic characteristics. A shelter facility and interpretive nature trail have been developed in the area. Needle Rock' is part of the Collorado Natural Areas Program and is one of the significant public land geologic features in Colorado as identified by the BLM's Geologic Advisory Group.

The entire management unit is designated as the Needle Rock Outstanding Natural Area/Area of Critical Environmental Concern (ONAACEC). This designation precludes all surface-disturbing activitles that are not consistent with management of the area for natural, scenic, and educational values. The area will be managed to protect these values and for recreation opportunities (sightseeing, picnicking, and geologic study) in a roaded but natural environment. A management plan will be developed.

Oil and Gas. Federal oil and gas estate will remain open to leasing with a no surface occupancy stipulation.

Locatable Minerals. The management unit will remain withdrawn from entry and location for locatable minerals.

Mineral Materials. The management unit will be closed to disposal of mineral materials.

Livestock Grazing. The management unit will remain unallotted for livestock grazing use.

Off-Road Vehicles. Vehicle use within the management unit will be limited to designated roads and trails yearlong.

Visual Resources. The management unit will be managed under VRM Class I guidelines.

Major Utilities. The management unit will be closed to development of major utility facilities. 
Fire Management. The entire management unlt will be managed under the fire suppression category and identified as an Intensive suppresslon area.

\section{MANAGEMENT UNIT 15}

6,783 Acres of Public Surface; 1 percent of the Planning Area

Management Unit 15 consists of 6,783 acres of public land approximately three miles northwest of Delta, Colorado. This area, commonly known as "the adobes", consists of Mancos shale hills and flats which, through wind and water erosion, have formed unlque scenic formations. The unit's solls are hlghly erodlble and sallne. Spring and summer storms frequently result in high sediment loads and very saline runoff.

The management unit also contains populations of the threatened Uinta Basin hookless cactus and is potential habitat for the endangered clay-loving wild buckwheat and the candidate Montrose penstemon.

The entire management unit is designated as the Adobe Badlands Outstanding Natural Area/Area of Critical Environmental Concern (ONAACEC). The area will be managed to protect its unique scenic qualities and threatened and endangered species' habitats, and to reduce active erosion.

The management unit will be protected from surface-disturbing activitles which degrade the area's scenic qualities and accelerate erosion. $A$ complete inventory for threatened and endangered specles will be conducted. Forage utllizatlon will be managed to achieve a basal groundcover of 10 percent. Ing.
OIl and Gas. Federal oll and gas estate will remain open to leasing with a no surface occupancy stipulation.

Mineral Materials. The management unit will be closed to the disposal of mineral materials.

Soils and Water Resources. Erosion and salinity control measures will not utilize structures or land treatments which would alter scenic values.

Threatened and Endangered Species. A complete inventory for threatened and endangered species will be conducted. Research and monitoring studies will be established.

Wild life Habitat. Wild life forage allocations will remain at current levels. No additional forage allocations will be made. To protect scenlc values, no new habitat improvement projects or maintenance of existing projects will be permitted.

Livestock Grazing. Livestock grazing will continue at current levels unless studies determine threatened and endangered plant species or their potential habitat are being degraded. If basal groundcover is less than 10 percent, livestock forage utilization will be managed at 35 percent utilization of key forage species. No additional forage allocations will be made. To protect scenic values, no new livestock improvement projects or maintenance of existing projects will be permitted.

Recreation. The unit will be managed for primitive non-motorized recreational use.

Off-Road Vehicles. The unit will be closed to ORV use to protect the scenlc qualities and to prevent accidental destructlon of threatened and endangered plant species and their potential habitat.

Visual Resources. To maintain its scenic qualities, the unit will be managed under VRM Class I guldelines. 
Major Utilities. The unit will be closed to the development of major utility facilities to prevent accidental destruction of threatened and endangered species and to maintain its scenic qualltles:

Fire Management. The unit will be managed under the fire suppression category and identified for conditlonal suppression.

\section{MANAGEMENT UNIT 16}

48,422 Acres of Public Surface; 10 percent of the Planning Area

In general, the public lands in Management Unit 16 ( $(48,422$ acres) will be managed according to the policy assumptions and standard resource program management guidance developed for the RMP. No activity plans will be written and no major BLM-funded projects or facilities will be developed within this area. Habitat, vegetation, and other resource studies will be minimal. Speciflc resource management in this area will be prescribed as follows:

Oil and Gas. Federal oil and gas estate will be open to leasing. A seasonal stipulation on seismic and drilling activities will be in effect from December 1 through April 30 on 1,042 acres of federal surface along the Gunnison and North Fork of the Gunnison rivers that are used by bald eagles as hunting habitat. Variances to the seasonal stipulation may be granted (see Appen$\operatorname{dix} A)$.
Locatable Minerals. The BOR withdrawals on Fruitland Mesa and along the Gunnlson River downstream of Delta will be recommended for revocation to allow for mineral exploration and development, facilitate resource management, permit long-tèrm land use planning, and allow for disposal of 806 acres of public land on Fruitland Mesa. Withdrawals on all other lands identifled for disposal will be recommended for revocatlon. Portions of withdrawals In the management unlt whlch will be affected, are those associated with 108 acres of the Paonia Project, 37 acres of the. Gunnison/Arkansas Project, 72 acres of the Uncompahgre Valley. Project, and 25 acres along the East Canal. Federal mineral estate will be open to entry and location after the withdrawal is revoked.

Forestry. The reserved federal timber (123 acres) on 160 acres of land deeded to the Girl Scouts of America will be removed from the timber base and not considered for harvest. The management and harvest of this timber would be inconsistent with use of the land as a Girl Scout camp.

Off-Road Vehicles, Public lands within the management unit will be open to ORV use.

Fire Management. A total of 48,422 acres of public land will be managed under the fire suppression category, with $12 ; 401$ acres identified for intensive suppression and 36,021 acres identified for conditional suppression. 


\section{CHAPTER THREE}

\section{SUMMARY OF MANAGEMENT DECISIONS BY RESOURCE.}

C hapter Three summarizes the RMP by resource and describes the monitoring of resource conditions needed to determine the effectiveness of the plan. Monitoring will also provide valuable resource information which will be used to guide future planning. Chapter Three also identifies: (1) present implementation priorities by resource and (2) any non-BLM'support needed to implement the planned actions: Although not identified in this chapter, the number one priority for all resource programs is to maintain each resource's base program. This includes normal administrative duties as well as responding to public inquiries and requests.

\section{LANDS. PROGRAM}

Management (Disposal, Acquisition, Access, Major Utilities)

\section{Disposal}

One hundred forty-three (143) tracts totalling 11,026 acres are identified for further consideration for disposal. The remaining 472,051 acres of public land managed by the BLM' will be retained in federal ownership. Until they are disposed of, potential disposal tracts will be managed according to the management prescription for the management unit in which they occur.

\section{Acquisition}

Private lands; if available, may be acquired in Management Unit 1 to improve livestock grazing management or to increase crucial deer and elk winter range; Management Unit 2 to increase crucial deer and elk winter range; Management
Unit 4 to improve recreational opportunities; Management 7 to improve riparian management or to increase crucial deer and elk winter range; Management Unit 9 to improve riparian management; and in Management Unit 11 to increase waterfowl nesting habitat.

\section{Access}

Public trail access will be acquired into the Dominquez WSA via the McCarty. Trail to provide public access to the sourtheast portion of the WSA.

Public road access will be acquired into the following areas: Olathe Reservoir for hunting and recreation; McDonald Mesa, Roatcap-Jay Creek, Spaulding Peak-Dry. Creek, Oak Mesa and Oak Ridge for hunting, recreation, wildlife habitat management and woodland harvest; Beaver Hill-Linscott Canyon for woodland harvest and recreation; the southwest side of the Gunnison River at the Gunnison Forks and the Gunnison River at Austin for recreation; Red Canyon for public access to the Gunnison Gorge WSA; Terror Creek for livestock administration and recreation; Storm King-High Park for commercial timber harvest and recreation.

Two miles of the Dry Fork of the Escalante Canyon Road will be closed to improve riparian vegetation.

Five miles of the Potter Creek Road will be closed to improve riparian vegetation.

\section{Major Utilities}

Since there are no significant resource conflicts Management Units $1,3,8,11$, and 16 will be open 
to major utillity development with minimal stipulations:

Management Unit 2 will be open to major utility. development with posslble restrictions on construction activities from December 1 through April 30 within crucial deer and elk winter range. to protect crucial deer and elk winter range from. disturbance.

Management Unit 4 will be closed to major utllity development except for the Smith Mountain Gunnison Forks area which would only be: open If no other feasible alternatives can be found to protect the areas scenic quality.

Management Unit 5 will be open to major utility. development with posslble restrictions on surface-dlsturbing activities: from March 1 through May. 31 to protect wet saline soils.

Management Units $6,12,14$, and 15 are closed to major utility development.

Management Unit 6 is closed to maintain its wilderness values.

Management Units 12, 14, and 15 are closed to protect their scenic quality.

Management Unit 7 will be closed to major utility development except for one-quarter mile either side of Highway 133 to preclude potential conflicts with coal leasing and extraction.

Management Unit 9 will be open to major utility development except no surface-disturbing activities which will have long-term adverse effects will be permitted to protect riparian vegetation.

Management Unit 10 will be open to major utllity development except no surface-disturbing activities will be permitted from May. 1 through June 15 to protect calving elk.

Management Unit 13 will be open to major utility development except pipelines and any. surface disturbance which would affect threatened or endangered plant species or their potential habitat.
Implementation,Priority

Priority 1. Prepare BLM protective withdrawal orders withdrawing from mineral entry and location in the following areas:

a. Portions of Management Unit 6 not currently under withdrawal

b. Management Unit 12

c. Management Unit 13

d. Management Unit 14

Priority 2. Prepare necessary documents to remove the BLM'protective withdrawal on those lands in Management Unit 4 currently. under withdrawal.

Priority 3. Complete route analysis and acquire public access: into the following areas:

a. Olathe Reservoir

b. Oak Mesa

c. Storm King-High Park

d. Beaver Hill-Linscott Canyon

e. McCarty. Trail

f. Roatcap-Jay. Creek

g. Spaulding Peak-Dry Creek

h. Red Canyon

i. Oak Ridge.

j. Terror Creek

k. McDonald Mesa

I. Gunnison River at Austin

m: southwest side of the Gunnison River at Gunnison Forks

Priority 4. Transfer reserved timber rights: on 160 acres to the Girl Scouts of America.

Priority 5. Process the transfer of the two landfill R\&PP leases: to Montrose County and Delta County.

Priority 6. Close and remove from the transportation plan five miles of the Potter Creek road and two miles of the Dry Fork of the Escalante road.

Priority 7. Work with the Bureau of Reclamation in lifting the existing BOR withdrawals for the 
Dominquez project and Fruitland Mesa project, and BOR withdrawals on identified potential disposal tracts:

Priority 8. Once all necessary reports have been completed, begin processing tracts which have passed through the disposal screens.

Priority 9. Acquire Identified private lands as opportunitles arise.

\section{Support}

A great deal of cooperation will be needed with Delta County. on the road closures; with the Bureau of Reclamation In liftlng BOR withdrawals; and with Montrose County and Delta County. In transferring the R\&PP leases:

\section{AIR QUALITY}

\section{Management}

Present air quality standards will be adhered to throughout the entire planning area. This is required by law.

\section{Implementation,Priority.}

Priority 1. Assist other agencies in obtaining baseline air quality data.

Priority 2. Incorporate mitigation into any project proposal which would degrade air quality.

\section{Support}

Support will be needed from the State of Colorado, Department of Health, Air Pollution Control Division; the U.S. Environmental Protection Agency; the U.S. Forest Service; and the National Park Service.

\section{MINERAL RESOURCES}

\section{Management}

\section{Coal}

Since there are no significant resource conflicts Management Units 1, 3, 4, 7, 8, and 16 are acceptable for further leasing consideration with no special restrictions.

Management Unit 2 will be acceptable for further leasing consideration with possible restrictions on surface-disturbing activitles from December 1 through April 30 on crucial deer and elk winter range to protect crucial deer and elk winter range from disturbance.

Mánagement Unit 5 will be acceptable for further leasing consideration with possible restrictlons on surface-disturbing activities from March 1 through May 31 to prevent excessive erosion on wet saline soils.

Management Units 6 and 15 will be closed to leasing.

Management Unit 6 will be closed to protect its wilderness values:

Management Unit 15 will be closed to protect its scenic quality.

Management Unit 9 may be acceptable for further leasing consideration on a site-specific basis after consultation with affected entities and formulation of mitigating measures designed to protect riparian vegetation.

Management Unit 10 will be acceptable for further leasing consideration with possible restriction on any disturbances from May. 1 through June 15 to protect elk calving areas.

Management Unit 11 will be acceptable for further leasing consideration with possible restrictions on any disturbance from March 15 through June 30 to protect nesting waterfowl.

Management Units 12,13 , and 14 are acceptable for further leasing consideration with pos- 
sible restrictions on surface-disturbing activities to protect threatened, endangered, or unique species and their potential habitat, and to protect scenic values.

\section{Oil and Gas}

Management Units $1,2,3,4,7$, and 16 are open to oil and gas leasing with seasonal stipulations from December 1 through April 30 on crucial deer and elk winter range and on bald eagle hunting habitat to protect crucial deer and elk winter range and bald eagle hunting habitat from disturbance.

Management Unit 5 will be open to oil and gas leasing with seasonal stipulations from March 1 through May 31 to protect wet saline soils:

Management Unit 6 is closed to oil and gasleasing to protect its wilderness values:

Since there are no significant resource conflicts Management Units 8 and 9 are open to oil and gas leasing with only standard stipulations.

Management Unit 10 will be open to oil and gas leasing with seasonal stipulations from May 1 through June 15 to protect elk calving areas.

Management Unit 11 will be open to oil and gas leasing with seasonal stipulations from March 15 through June 30 to protect nesting waterfowl, and from December 1 through April 30 on bald eagle hunting habitat to protect bald eagle hunting habitat from disturbance.

Mánagement Units $12,13,14$, and 15 are open to oil and gas leasing with a no surface occupancy stipulation to protect threatened and endangered species habitat and the areas scenic quality.

\section{Locatable Minerals}

Management Units 1, 2, 3, 4, 5, 7, 8, 9, 10, 11, 15 , and 16 are open to mineral entry and location due to the lack of resource conflicts. Existing
BLM and BOR withdrawals will be recommended for lifting as they are no longer needed.

Mánagement Units $6,12,13$, and 14 are closed to mineral entry and location. These units will be placed under a BLM protective withdrawal.

Management Unit 6 is closed to protect its wilderness values.

Management Units 12 and 13 are closed to protect threatened, endangered and unique plant habitat.

Mánagement Unit 14 is closed to protect its scenic quality.

\section{Mineral Materials}

Since there are no significant resource conflicts Management Units $1,3,4,7,8,10$, and 16 are open to mineral material disposal.

Management Unit 2 is open to mineral material disposal with possible restrictions on surfacedisturbing activities from December 1 through April 30 on crucial deer and elk winter range to protect crucial deer and elk winter range from disturbance.

Management Unit 5 is open to mineral material disposal with possible restrictions on surfacedisturbing activities from March 1 through May 31 on wet saline soils to protect wet saline soils from rutting and erosion.

Management Units $6,9,12,13,14$, and 15 are closed to mineral material disposal.

Management Unit 6 is closed to protect its wilderness values:

Management Unit 9 is closed to protect riparian vegetation.

Management Units 12 and 13 are closed to protect threatened, endangered and unique plant habitat.

Management Units 14 and 15 are closed to protect their scenic quality. 
Management Unit 11 is open to mineral materlal dlsposal with possible restrictlons on any disturbance from March 15 through June 30 to protect nesting waterfowl.

\section{Implementation।Priority.}

Priority. 1. Revise oil and gas stipulations sheets:

Priority 2. Prepare a map of areas requiring a plan of operation (areas open to entry. and location but closed to ORV).

Priority 3. Prepare mineral reports on acreages: of federal mineral estate to be withdrawn:

a. Portlons of Management Unit 6 presently not withdrawn.

b. Management Unit 12

c. Management Unit 13

d. Management Unit 14

Priority 4. Prepare a map of special coal lease stipulation areas.

Priority 5. Establish common use mineral material areas and revise the Umbrella Mlneral Màterlals E.A.

Priority 6. Prepare mineral reports on the potentlal disposal tracts.

\section{Support}

Support will be needed from the Regional Coal Team in identifying tracts for coal leasing.

\section{SOIL AND WATER RESOURCES}

\section{Management}

Water quality and erosion conditions will continue to be monitored throughout the planning area to establish baseline conditions, identify. problem areas and to measure changes due to management actions. Management Units 1, 2 , $3,7,8,9,10,11,12,13,14$, and 15 are available for erosion and sallnity. control objectives and projects which do not conflict with the primary objectives of each of these management units:

Management Unit 4 will be available for erosion and salinity control objectives and projects designed to reduce erosion and salinlty. The Elephant Skin Salinity. Control Project will be malntained and protected from disturbance to extend the projects effectiveness.

Watershed Mánagement objectlves will be developed for Management Unit 5. The objectives will be designed to reduce downstream salinity.

Projects will be developed in Management Unit 6 only if life, property, or wilderness values are threatened to protect the areas wilderness values. Director approval is needed for any projects.

Management Unit 16 will not be available for any project development due to the low potential economic return.

\section{ImplementationıPriority}

Priority 1. Maintain existing water quality and erosion monitoring studies.

Priority 2. Amend the Elephant Skin Salinity Control Plan to conform to this RMP.

Priority 3. Determine existing basal ground cover on:

a. The Elephant Skin project area

b. Management Unit 15

c. Management Unit 5

Priority 4. Develop Watershed Management objectives on Management Unit 5.

Priority 5. Implement Watershed Management Plans: 
Support

Support will be needed from the Colorado Water Quality. Control Division and the Environmental Protection Agency.

\section{RIPARIAN/AQUATIC SYSTEMS}

\section{Management}

Management Units $1,2,3,4,5,6,7,8,10,11$, $12,13,14,15$, and 16 will continue to be inventoried and monitored as per BLM policy. Riparian vegetation condition will, at a minimum, be malntained or preferably improved. Measures designed to mitigate adverse riparlan impacts will be required for all surface-disturbing activities:

Riparian Improvement Plans will be prepared for Management Unit 9. These plans will be designed to improve riparian vegetation condition in these areas. This intensive management is designed to accelerate riparian improvement.

\section{Implementation,Priority}

Priority 1. Maintain existing studies designed to monitor riparian vegetation trends.

Priority 2. Inventory riparian vegetatlon condltion on the following streams:
a. Cottonwood Creek
b. Spring Creek
c. Escalante Creek
d. Terror Creek
e. Jay Creek
f. Current Creek
g. Dry fork of Escalante Creek
h. remaining riparian areas

Priority 3. Update existing AMPs, HMPs; RAMPs; and WMPs to incorporate riparian objectives if needed.
Priority 4. Establish new studies in Management Unit 9 designed to determine the best means of riparian improvement.

Priority 5. Prepare riparian improvement plans on:

a. Roubldeau Creek and its tributaries

b. remaining creeks in Management Unit 9

Priority 6. Physically close and rehabilitate the the Potter Creek and Dry. Fork of Escalante. Creek.

\section{Support}

No support will be needed.

THREATENED: AND ENDANGERED SPECIES.

\section{Management}

Clearances and mitigation for threatened and endangered species will be required for all surface-disturblng activities throughout the planning area. This is required by law.

Management Units $1,2,3,4,5,6,7,9,10,11$, 14 , and 16 will have measures designed to protect threatened and endangered species and their habitat incorporated into all activity. plans: This management will further enhance. threatened and endangered species protection.

Management Unit 8 will be inventorled for threatened and endangered species and its boundary adjusted to exclude any located plants. This management will eliminate any potential destruction of threatened and endangered plants:

Management Unit 12 is designated an Area of Critical Environmental Concern (ACEC) and Management Unit 15 is designated an OutstandIng Natural Area/Area of Critical Environmental 
Concern (ONAACEC) in part due to the occurrence of several threatened and endangered species and unique plant associations. Management plans will be developed for these areas and Intensive studies established to increase our basicknowledge about these threatened and endangered species:

Management Unit 13 is designated a Research Natural Area/Area of Critical Environmental Concern (RNAACEC). A management plan will be developed for this area and intensive studies established to increase basic knowledge about these threatened and endangered species.

\section{Implementation Priority.}

Priority 1. Conduct a threatened and endangered species inventory of Management Unit 8.

Priority 2. Prepare the management plan for Management Unit 13 and assist the preparation of a management plan for Management Unit 12.

Priority 3. Establish studies in Management Units 12 and 13 designed to determine how best to Increase plant frequency.

Priority 4. Conduct a threatened and endangered species inventory. In Management Unit 15.

Priority 5. Conduct threatened and endangered species clearances on potential disposal tracts:

Priority 6. Continue general monitoring of threatened and endangered species:

\section{Support}

Support is needed from the U.S. Fish and Wildlife Service and the Colorado Natural Areas: Program.

\section{WILDLIFE.HABITAT}

\section{Management}

Additional forage will be available in Management Unit 1 for wildlife only if not needed by. livestock to increase forage available for livestock grazing. Non-conflicting wildlife objectives and projects will be incorporated into existing allotment management plans to eliminate the need for multiple activity plans. Desert bighorn sheep will be permitted on Winter Mesa if it is determined there would be no conflict with livestock. This will Increase population numbers; re-establish this species in previously occupled habitat and insure species viability in this area.

Wildlife will have priority for any additional forage in Management Unit 2. Habitat management plans will be developed to improve winter range. Desert bighorn sheep may. be reintroduced into the Camel Back-Roubideau area to increase population numbers and provide genetic diversity.

Mánagement Units $3,4,5,8,9,11,12,13,14$, and 15 will have habitat trend studies established on all crucial deer and elk winter range to monitor habitat changes. Additional forage will be dlvided equally between wildlife and livestock to provide forage for both resources. Supplemental releases and reintroduction of wildlife species may be authorized to increase population numbers:

Bighorn sheep will be protected and habitat improved in Management Unit 4 to enhance habitat conditions and increase population numbers.

Management Unit 6 will be managed for a natural distribution of wildlife populations to protect the areas wilderness values. Additional supplemental releases of bighorn sheep will be permitted to increase population numbers and enhance genetic viability.

Wildlife will have priority for any additional forage in Management Unit 7 to increase available forage on public land. 
Wildlife will have priority for any additional forage In Management Unit 10 to Increase available forage. A habltat management plan will be prepared to improve elk calving habitat.

Management Unit 11 will be managed to improve waterfowl nesting habitat. This will be accomplished in cooperation with the adjoining Colorado DOW. Wildlife Area.

No additional forage in Management Unit 15 will be allocated, no exlstlng projects will be malntained, and no new projects will be developed. This management will protect the areas scenic qualities:

Implementation

Priority 1. Cooperate with the Colorado DOW. on supplemental releases of bighorn sheep into the Gunnison Gorge.

Priority 2. Establish and maintain monitoring studies on crucial deer and elk winter range to determine habltat condition and trend.

Priority 3. Cooperate with the Colorado DOW. on reintroduction of desert bighorn sheep Into the Camel Back area.

Priority 4. Prepare habitat management plans in the following areas:

a. Baldy Peak

b. Jumbo Mountaln-McDonald Mesa

c. Grand Mesa

d. Management Unit 11

e. Uncompahgre Plateau

f. Billy Creek

g. Management Unit 10

Priority 5. Incorporate the Gunnison Forks HMP into the Gunnison Gorge RAMP.

\section{Support}

Support is needed from the Colorado Division of Wildlife.

\section{LIVESTOCK GRAZING}

\section{Management}

Management Units $3,8,11,12,13$, and 16 will maintain current forage allocations for livestock grazing until studies determine adjustments are needed. Additional forage will be divided equally between livestock grazing and wildlife to provide forage for both resources: Livestock grazing will be limited to 50 percent utilizatlon of key. forage species to permit sustalned forage capacity.

Management Unit 1 will be Intensively managed to improve vegetation conditlons and livestock forage. Livestock grazing will have first prlority for any additional forage to increase forage available for livestock grazing. Allotment management plans will be prepared to identify grazing management practices: Any.unallotted areas or relinquished permits will be reissued to permit livestock grazlng.

In Management Unit 2 any proposed projects must be compatible with wildlife objectives. Additional forage will be available for livestock use only if not needed by wildlife.

In Management Unit 3 no projects will be permitted which would reduce the woodland base. This management will Increase production of woodland products.

In Management Unit 4 livestock grazing will be limited to 35 percent utilization of key forage species in the Elephant Skin Salinity Control Project if needed to obtain optimum cover. No grazing will be permitted in the Gunnison Forks HMP area in order to eliminate livestock-recreation conflicts:

In Management Unit 5 additional forage will be divided equally between livestock grazing and wildlife to provide forage for both resources. No livestock will be permitted from March 20 to range readiness to protect wet saline solls. Livestock use will be limited to 35 percent utiliza- 
tion of key forage species until basal ground cover objectives are attained to reduce erosion.

In Management Unit 6 livestock grazing and project maintenance will be limited to levels and conditions established prior to wilderness designation to protect the areas wilderness values. New projects may be authorized if necessary for rangeland and/or wilderness protection.

Any additional forage in Management Unit 7 will be allocated to wildlife to increase available forage on public land.

No fences or other projects which would impede ORV use will be permitted in Management Unit 8 to eliminate ORV hazards.

No livestock grazing will be allowed in Management Unit 9 from March 1 to range readiness to accelerate riparian vegetation improvement. Livestock grazing may be limited to 35 percent utilization of key forage species to increase riparian cover. Trailing use will be confined to established roads and limited as much as possible. No bedding livestock will be permitted in riparian areas to reduce bank disturbance.

Wildlife will have first priority for any additional forage in Management Unit 10 to increase available forage.

In Management Units 12 and 13 livestock grazing will continue at current levels unless studies determine threatened or endangered or unique. species and their potential habitat are being adversely. affected. This is designed to protect threatened, endangered and unique species from potential livestock destruction.

Management Unit 14 will be closed to livestock use to protect its scenic qualities:

Livestock grazing will continue at current levels in Management Unit 15 unless studies determine threatened and endangered species and their potential habitat are being adversely affected. This is designed to protect threatened and en- dangered species from potential livestock destruction. Livestock grazing use will belimited to 35 percent utilization of key forage species until basal ground cover objectives are attained to increase cover thereby reducing erosion. No additional forage allocations for livestock will be made. No existing projects will be maintained and no new projects will be developed to protect the areas scenic qualities.

\section{Implementation,Priority}

Priority 1. Continue existing vegetation trend studies:

Priority 2. Increase monitoring of actual livestock trailing use of Management Unit 9:

a. Roubideau Creek

b. Roatcap-Jay Creek

c. Remaining riparian areas in Management Unit 9

Priority 3. Establish and maintain vegetation condition studies in Management Unit 1.

Priority 4. Limit grazing permits on allotments containing potential disposal tracts to one year. Adjust AUM'allocations as tracts are exchanged or sold.

Priority 5. Change livestock season of use in Management Units 5 and 9 to exclude livestock grazing from March 1 to range readiness.

Priority 6. Evaluate and update existing AMPs to reflect decisions in this RMP.

Priority 7. Develop new AMPs on grazing allotments without current plans in Management Unit 1.

Priority 8. Implement new AMPs as funds become available.

\section{Support}

Support is needed from the Montrose District Grazing Advisory Board. 


\section{FORESTRY}

\section{Management}

In Management Unlt 1 the forest resource will be managed to increase livestock forage.

In Management Unit 2 the forest resource will be managed to improve wild life habitat with possible restrictions on surface-disturbing activities from December 1 through April 30 on crucial deer and elk winter range to protect crucial deer and elk winter range and its use from disturbance.

In Management Unit 3 the forest resource would be intensively managed for woodland product harvest within sustained yield production limits: to increase available woodland products. Forest Management Plans would be prepared and, if needed, plantations established to increase forest product availability.

In Management Unit 4 the only area open to woodland product harvest is 1,255 acres in the Black Ridge area. This area may have restrictions on surface-disturbing activities from December 1 through April 30 within crucial deer and elk winter range to protect crucial deer and elk winter range from disturbance.

Management Units $5,7,8,11,13,15$, and 16 will be managed for sustained yield production of forest products to meet current and future demands for woodland products.

Management Unit 6 will not be available for woodland harvest except for insect or disease control efforts to protect its wilderness values.

Management Units 9,12 , and 14 are closed to harvest.

Management Unit 9 is closed to protect riparian vegetation.

Management Units 12 and 14 are closed to protect their scenic values:
Management Unit 10 will have timber and woodland harvests designed to improve elk calving habitat.

ImplementationıPriority.

Priority 1. Rewrite the Umbrella Forest Products environmental assessment to conform to this RMP.

Priority 2. Assist In the preparation of a management plan for Mánagement Unit 10.

Priority 3. Prepare Forest Management Plans: for the following areas:
a. Jones: Draw
b. Highway 90
c. North Escalante
d. Lee Point
e. Beaver Hill
f. Dirty George
g. Youngs Peak
h. Sawmill Mesa
i. West Transfer Road
j. Dry Creek
k. Government Springs
I. Loghill

\section{Support}

Support is needed from the Colorado Division of Wildlife.

\section{RECREATION}

\section{Management}

River access will be developed at the Escalante Bridge site in Management Unit 1 to provide an improved landing area. Maps and informational pamphlets will be prepared to limit boater landowner conflicts along the lower Gunnison River between Delta and Bridgeport. 
Management Units 2, 3, 5, 7, 9, 10, 11, 13, and 16 will be managed for extensive recreational use to meet public demands for dispersed recreatlon.

Management Unlt 4 will be managed for recreatlonal use. The Peach Valley area will be managed predominately for ORV use while the remalnder will be managed for its natural primitlve values: Thls management is designed to meet a wide variety of recreational demands:

Mànagement Unit 6 will be managed for low impact non-motorized recreational use. Permits may be required for commercial and non-commercial use: The Gunnison River will be managed for six to ten group encounters per day, with only two (as per the 1988 Gunnison Gorge RAMP) commercial trips per day. This management is designed to protect the areas wilderness values:

Management Unit 8 will be developed for intensive ORV use. Loading ramps and informational signs will be constructed. This management will provide ORV users: an area with limited hazards:

Mánagement Unit 12 will be designated an Area of Critical Environmental Concern (ACEC) to protect the areas threatened and endangered species and recreational values. Informational signs and warnings will be posted at the Potholes to inform the public of the hazards:

Management Unit 14 will be designated an Outstanding Natural Area/Area of Critical Environmental Concern (ONA/ACEC) to protect the areas scenic qualities: A management plan will be prepared.

Management Unit 15 will be designated an Outstanding Natural Area (ONA/ACEC) to protect the areas threatened and endangered species and scenic qualties. A management plan will be prepared to manage the area for its primitive, non-motorized recreational values:
Implementation Priority.

Priority 1. Revise the Gunnison Gorge RAMP or prepare an RMP amendment to bring these two documents into conformance.

Priority 2. Implement the Gunnison Gorge RAMP.

Priority 3. Prepare and implement a management plan for Management Unit 14.

Priority 4. Prepare maps and informational pamphlets for the lower Gunnison River.

Priority 5. Construct a ramp at the Escalante. Bridge.

Priority 6. Prepare and implement a management plan for Mánagement Unit 12.

Priority 7. Prepare and implement a management plan for Management Unit 8.

Priority 8. Prepare and implement a management plan for Management Unit 15.

Priority 9. Construct the McCarty. Trail trailhead.

Support

No support will be needed.

OFF-ROAD: VEHICLE, MANAGEMENT

Management

See the map in Appendix C.

Implementation।Priority.

Priority 1. Signing and public informational maps: 


\section{Support}

No support will be needed.

\section{CULTURAL RESOURCES}

\section{Management}

Clearances and mitigation for cultural resources will be required for all surface-disturbing activitles throughout the planning area. This is required by law.

Management Unit 1 will have a Class III cultural inventory conducted on 5,800 acres between Highway 90 and Sandy. Wash to Identify. the presence of cultural resources and determine the areas cultural significance.

Management Units 2, 3, 4, 5, 6, 7, 8, 9, 10, 11 , $12,13,14,15$, and 16 will have measures designed to protect cultural sites incorporated into all activity plans. This is required by law.

\section{Implementation IPriority.}

Priority 1. Survey all potential disposal tracts.

Priority 2. Conduct a Class: III survey on 5,800 acres in Management Unit 1.

Priority 3. Identify other sensitive areas based on modeling.

\section{Support}

Support will be needed from the Colorado State Historic Preservation Officer.

\section{PALEONTOLOGICAL RESOURCES.}

\section{Management}

Protective measures will be developed as this resource is discovered. Little is known about this resource in this area. As Information is obtained specific management will be identified.

Implementation IPriority

No implementation is scheduled.

\section{Support}

No support will be needed.

\section{VISUAL RESOURCES}

Management

Management Unit 1 will be managed under VRM Class III, except for Escalante Canyon which will be Class II to protect its scenic qualities.

Management Unit 2 will be managed under VRM'Class III to protect its scenic qualities while permitting some intrusion.

Mánagement Units $3,5,7,9,10,11,13$, and 16 will be managed under the existing VRM' classifications as no changes were deemed necessary.

Management Unit 4 will be managed under the existing VRM'classes, except for open ORV areas which will be managed under VRM' Class IV to allow substantial change.

Mànagement Unit 6, 14, and 15 will be managed under VRM ' Class I to protect the area's scenlc qualities:

Management Unit 8 will be managed under VRM'Class IV to allow substantial change.

Management Unit 12 will be managed under VRM Class II to protect its scenic qualities.

Implementation Priority 
Decisions by Resource

No Implementation is scheduled.

Support

No support will be needed.

WILDERNESS.

Management

Management Unit 6 will be recommended as suitable for wilderness designation to protect its wilderness values.

Implementation Priority.

Priority 1. Prepare the Final Wilderness: EIS.
Chapter Three

Priority 2. Prepare the Wilderness Study Report for each of the three Wilderness Study. Areas:

FIRE.

Management

Fire will be managed as displayed on the map in Appendix $\mathrm{D}$. This management is based on resource conditions; proximity of private development and risk of fire spread.

Implementation Priority.

No implementation is scheduled.

Support

No support will be needed.

41 



\section{APPENDIX A}

\section{STIPULATIONS FOR OIL AND GAS LEASES}

T The following stipulations wili be added to future oil and gas leases on both federal surface and split-estate lands where assigned for each management unit (see beginning page 146). The actual wording of these stipulations may be adjusted at the time of leasing to reflect future iegisiation, court decisions or poilicy changes; however, the protection standards contained in these stipulations will be maintained. Any change to the protection content of the stipulation would require an amendment to the RMP/EIS.

\section{Highly Erodible and/or Saline Soil Areas}

Stipulation: To protect watersheds from salinity infusions and to protect highiy erodibie soli areas where low soil productivity would prolong or disailow revegetation, all development activities (expioration, drilling, etc.) will be allowed only from June 1 through February 28. Exceptions to this limitation may be authorized in writing by the BLM's Authorized Officer. The affected portions of this lease are (iegai description).

Reasons for Exceptions: This stipulation may be walved, excepted, or modified by the Authorized Officer if the lessee can demonstrate that operations can be conducted without causing unacceptable impacts on salinity and highiy erodible soil areas. The stipuiation will not be walved, excepted, or modlfied if it is determined that the activity would cause acceierated erosion that wouid result in excessive amounts of sainity being contributed to the Coiorado River. Variances couid be allowed if soils are not saturated during the typical high soil moisture period when these these soils are most susceptible to damage (March 1 through May 31), or if impacts could be mitigated, or if site-specific conditions do not warrant the stipuiation (smail amount of disturbance, short duration of operations, etc.).

Resource information for split-estate lands has not been verified by the BLM. Verification wiil occur during review of Appiications for Permit to Drill (APD's). On-site inspection and consultation with the surface owner and operator may reveal that (1) the impacts addressed by the stipulation will be avoided or mitigated to an acceptable level, or (2) the resources of concern are not present. Upon either of these determinations by the Authorized Office, the stipuiations can be waived, modified, or excepted without public notice other than that provided for the APD. if, after on-site inspection and consuitation with the private surface landowner, it is determined by the Authorized Officer that conditions necessary to avoid impacts to private resources wouid adversely impact the pubiic resources addressed by these stipulations, the impacts wili be assessed. if, based upon such assessment, the Authorized Officer makes a decision to substantially change or waive one or more stipulations, a 30-day public review period wili be provided in addition to the public notice period for receipt of the APD. (These two 30-day notice and review periods may overiap.)

2. Threatened, Endangered, Candidate, and Sensitive Plant Areas

Stipulation: To protect the threatened, endangered, candidate, and sensitive plants and their potentiai habitat within the Escalante Canyon Area of Critical Environmental Concern and the Fairview Research Natural Area, an area of critical environmental concern, no surface occupancy will be permitted in these areas. Excep- 
tions to this restriction may be authorized in writing by the BLM's Authorized Officer. The affected portions of this lease are (legal description).

Reasons for Exceptions: This stipulation may be walved, excepted, or modified by the Authorized Officer Is the lessee can demonstrate that operations can be conducted without causIng unacceptable impacts on threatened, endangered, candidate, and sensitive plants and their potential habitats within these areas.

\section{Bald Eagle Winter Concentration Areas}

Stipulation: To protect bald eagles from activities that would cause abandonment of winter concentration areas, all development activities (exploration, drilling, etc.) will only be allowed in these areas from May 1 through November 30. Exceptions to this limitation may be authorized in writing by the BLM's Authorized Officer. The affected portions of this lease are (legal descriptlon).

Reasons for Exceptions: This stipulation may be waived, excepted, or modified by the Authorized Officer if the lessee can demonstrate that operations can be conducted without causing unacceptable impacts on wintering bald eagles.

Resource information for split-estate lands has not been verifled by the BLM. Verification wili occur during revlew of Applications for Permit to Drill (APDs). On-site inspection and consuitation with the surface owner and operator may reveal that (1) the impacts addressed by the stipulation will be avolded or mitigated to an acceptable level, or (2) the resources of concern are not present. Upon either of these determinations by the Authorized Officer, the stipulations can be waived, modified, or excepted without public notice other than that provlded for the APD. If, after on-site inspection and consultation with the private surface landowner, it is determined by the Authorized Officer that conditions necessary to avoid impacts to private resources would adversely impact the public resources addressed by these stipulations, the impacts will be assessed. if, based upon such assessment, the Authorized Officer makes a decision to substantiaily change or waive one or more stipulations, a 30-day public review period will be provided in addition to the public notice period for recelpt of the APD. (These two 30-day notice and review periods may overlap.)

\section{Crucial Deer and Elk Winter Ranges}

Stipulation: To protect crucial deer and elk winter ranges from activities that would cause these species to abandon areas of crucial winter forage and cover for less suitable ranges, all development activities (exploration, drilling, etc.) will only be allowed from May 1 through November 30. Exceptions to this limitation may be authorized in writing by the BLM's Authorized Officer. The affected portions of this lease are (legal description).

Reasons for Exceptions: This stipulation may be walved, excepted, or modifled by the Authorized Officer if the lessee can demonstrate that operations can be conducted without causing unacceptable impacts on deer and elk utillzation of crucial winter ranges. Variances could be allowed if these crucial ranges are not being utilized due to mild winter conditions or temporary changes in winter range utllization, or if impacts could be mitigated, or if site-specific conditions do not warrant the stipulation (small amount of dlsturbance, short duration of operations, etc.).

Resource information for split-estate lands has not been verified by the BLM. Verification wili occur during review of Applications for Permit to Drill (APDs). On-site inspection and consuitation with the surface owner and operator may reveal that (1) the impacts addressed by the stlpulation will be avoided or mitlgated to an acceptable level, or (2) the resources of concern are not present. Upon either of these determinatlons by the Authorized Officer, the stipulations 
can be walved, modifled, or excepted without pubilc notlce other than that provlded for the APD. If, after on-slte inspection and consultation with the private surface landowner, it is determined by the Authorized Officer that conditions necessary to avoid impacts to private resources would adversely Impact the public resources addressed by these stipulations, the impacts will be assessed. If, based upon such assessment, the Authorlzed Officer makes a decision to substantlally change or waive one or more stipulations, a 30-day public review period will be provided in addition to the public notice period for receipt of the APD. (These two 30-day notice and review periods may overlap.)

\section{Elk Calving Areas}

Stipulation: To protect elk calving areas from activities that would force elk to abandon these areas during criticai calving periods, ail development activitles (exploratlon, drllling, etc.) will only be allowed from July 16 through April 14 . Exceptions to this limitation may be authorized in writing by the BLM's Authorized Officer. The affected portions of this lease are (legal description.

Reasons for Exceptions: This stipulation may be waived, excepted, or modified by the Authorized Officer if the lessee can demonstrate that operatlons can be conducted without causing unacceptable impacts on deer and elk utilization of crucial winter ranges.

Resource Informatlon for split-estate iands has not been verified by the BLM. Verification will occur during revlew of Applications for Permit to Drill (APDs). On-site Inspection and consultation with the surface owner and operator may reveal that (1) the impacts addressed by the stipulation will be avoided or mitigated to an acceptable level, or (2) the resources of concern are not present. Upon either of these determinations by the Authorized Officer, the stipuiations can be waived, modified, or excepted without public notice other than that provided for the
APD. If, after on-site inspectlon and consultation with the private surface landowner, it is determined by the Authorized Officer that conditions necessary to avoid impacts to private resources would adversely impact the public resources addressed by these stipulations, the impacts will be assessed. If, based upon such assessment, the Authorized Officer makes a decision to substantially change or waive one or more stipulations, a 30-day public review period will be provided in addition to the public notice period for receipt of the APD. (These two 30-day notice and review periods may overlap.)

\section{Waterfowl Habitat}

Stipulation: To protect waterfowl from activities that would alter breeding behavior, increase the incidence of nest abandonment, and decrease breeding success, all development activities (expioration, drilling, etc.) will only be allowed in waterfowl habitats from July 1 through March 14. Exceptions to thls limitation may be authorized in writing by the BLM's Authorized Officer. The affected portions of this lease are (legal description).

Reasons for Exceptions: This stipulation may be waived, excepted, or modified by the Authorized Officer if the lessee can demonstrate that operations can be conducted without causing unacceptable impacts on breeding and nesting waterfowl. Variances could be allowed if these breeding habitats are not being utilized, or if impacts could be mitigated, or if site-speciflc conditions do not warrant the stipulation (few individuals affected, short duration of operations, etc.).

Resource information for split-estate lands has not been verifled by the BLM. Verification will occur during review of Applications for Permit to Drill (APDs). On-site inspection and consultation with the surface owner and operator may reveal that (1) the impacts addressed by the stipulation will be avoided or mitigated to an acceptabie level, or (2) the resources of concern 
are not present. Upon either of these determinations by the Authorized Officer, the stipulations can be waived, modified, or excepted without public notlce other than that provided for the APD. If, after on-site inspection and consultation with the private surface landowner, it is determined by the Authorized Officer that conditions necessary to avoid impacts to private resources would adversely impact the public resources addressed by these stipulations; the impacts will be: assessed. If, based upon such assessment, the Authorized Officer makes a decision to substantially change or waive one or more stipulations; a 30-day public review period will be provided In addition to the public notice period for receipt of the APD. (These two 30-day notice and review periods may overlap.)

\section{Outstanding Natural Areas/Areas of Criti- cal Environmental Concern!}

Stipulation: To protect the scenic, natural, and scientific values of the Adobe Badlands Outstanding Natural Area/Area of Critical Environmental Concern, and the Needle Rock Outstanding Natural Area/Area of Critical Environmental Concern, no surface occupancy will be permitted within these areas. Exceptions to this resiriction may be authorized in writing by the BLM's Authorized Officer. The affected portions of this lease are (legal description).

Reasons for Exceptions: This'stipulation may be waived, excepted, or modified by. the Authorized Officer if the lessee can demonstrate that operations can be conducted without causing unacceptable impacts on the scenic, natural, and scientific values of these areas.

\section{Wilderness Study. Areas}

Stipulation: Wilderness Protection Stipulation Form CSO 3000-1 (July 1980) is attached per Washington Office Instruction Memo No. 80-509 $(5 / 12 / 80)$. This memo implements the Interim Management Pollcy and Guidelines: for Land Under Wilderness Review (12/12/79) and amendments).

Reasons for Exceptions: This stipulation will be attached to all leases involving lands within WSAs; and will apply. until these lands are released from WSA status. 


\section{APPENDIX B}

\section{COAL PLANNING}

T he following is a summary of the Coal planning process for the Uncompahgre Basin RMP. Detailed and specific information is available in the Coal Unsuitability. Report. This report is available at the Uncompahgre Basin Resource Area Office and the Montrose District Office.

The Federal Coal Leasing Amendment Act of 1976 outlines procedures for leasing and development of federally-owned coal lands. This Act requires that coal leasing be compatible with land use allocations outlines in comprehensive land use plans: The Surface Mlning Control and Reclamation Act of 1977 established federal standards: for regulating surface mining and reclamation activities on federal, state, and private lands. The Department of Interior has incorporated these Acts into regulations requiring the analysis of four coal planning screens during land use planning. Documented in Title 43, Code of Federal Regulations-Part 3420.1 (43 CFR 3420.1), these planning screens are applied to determine the leaseability of federal coal lands.

The first screen (coal development potential) eliminates federal coal lands that have little or no coal development potential. The second screen (coal unsuitability review) eliminates lands that have sensitive resources: The third screen (multiple-use tradeoffs) eliminates lands that have resources considered more important than coal or identifies lands where special stipulations are required to protect important resources. The fourth screen (surface owner consultation) eliminates private land with federal coal based on the landowner's opposition to surface mining.

The first coal planning screen was completed prior to 1980 when the U.S. Geological Survey
(USGS) identified as coal planning areas all the federal coal lands within the region that have coal development potential. The Bookcliffs (965 acres), Paonia/Somerset (94,960 acres), and Cimarron Ridge $(14,134$ acres) coal planning areas were identified within the Uncompahgre Basin planning area.

Federal coal lands passing through the first coal planning screen are subject to application of the 20 coal unsuitability criteria in the second coal planning screen. These 20 criteria, outlines in Title 43, Code of Federal Regulations-Part 3461.1 (43 CFR 3461.1 ), are a uniform national standard to insure that 20 specific resources and land uses are not foregone by coal mining. Federal coal lands not meeting the standards required by each criterion are determined to be unsuitable for coal leasing. A number of criteria have exemptions and exceptions. Application of these exemptions and exceptions may allow certain types of coal mining.

A total of 20,945 acres of federal coal lands are presently leased and were not subject to the second coal planning screen as per 43 CFR 3461.4-2. An additional 5,718 acres of presently. leased federal coal lands were previously determined to be suitable as identified in the following documents: the North Fork MFP as amended; and the environmental assessments for the West Elk Coal Company Coal Lease Modificatlon Application (Serial Number D-044569), the Colorado Westmoreland, Inc., and Western Slope Carbon, Inc., Short-Term Competitive Coal Lease Applications (Serial Numbers C27432 and C-27103), and the Grand Mesa Properties Company. Coal Lease Modification Application (Serial Number D-055156). 
Appendix

All portions of the coal planning areas within the Uncompahgre Basin planning area that are not leased for coal development are undergoing the second coal planning screen in concurrence with this RMP/EIS. These unleased federal coal lands total 83,396 acres in the Bookcliffs and Paonia/Somerset coal planning areas.

Based on initial application of the 20 criteria, 82,827 acres were determined to be acceptable for further coal leasing consideration. Of these lands, 15,662 acres were determined to be suitable only with specified constraints. Lands determined to be unsuitable for further leasing consideration total 569 acres. No exemptions were determined to apply within the review area. Prior to the leasing of a federal coat tract, the results of this coal planning screen will be reviewed on a site-specific basis to determine if any changes are necessary in the application of the 20 criteria.

Public lands that have resources determined to be more important than coal development are either protected by special stipulations or eliminated from coal leasing consideration in the third coal planning screen. These multiple-use trade-off determinations are made during the RMP/EIS process. This RMP/EIS fulfills the requirements of the third coal planning screen for all of the federal coal within the planning area, including existing leased lands.

The fourth coal planning screen requires consiltation with the owners of split-estate lands when federal coal is being considered for leasing and surface mining techniques are considered likely. This coal planning screen was determined to not apply to the coal planning areas within the Uncompahgre Basin planning area as no surface mining of significant amounts of coal is anticipated.

Information derived from completion of these four coal planning screens is forwarded to the appropriate interagency Regional Coal Team.

48 


\section{APPENDIX C}

OFF-ROAD VEHICLE MANAGEMENT

Map \#1

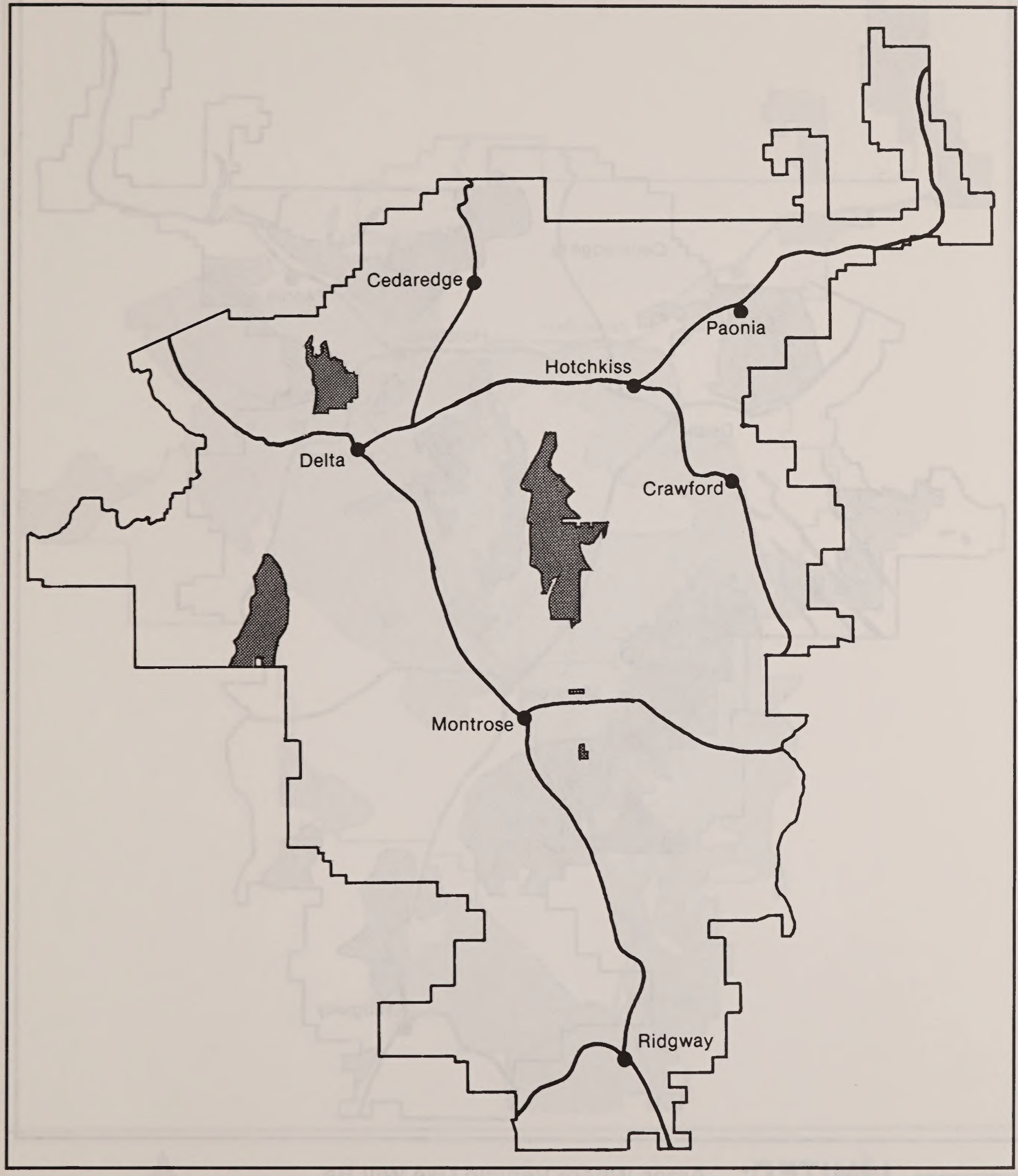

CLOSED: Areas Which Are Closed to Off-road Vehicle Use Year-round.

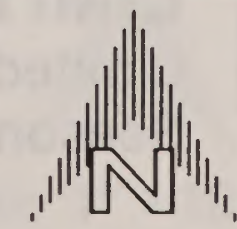

Scale: $1^{\prime \prime}=10$ Miles 


\section{APPENDIX C}

OFF-ROAD VEHICLE MANAGEMENT

Map \#2

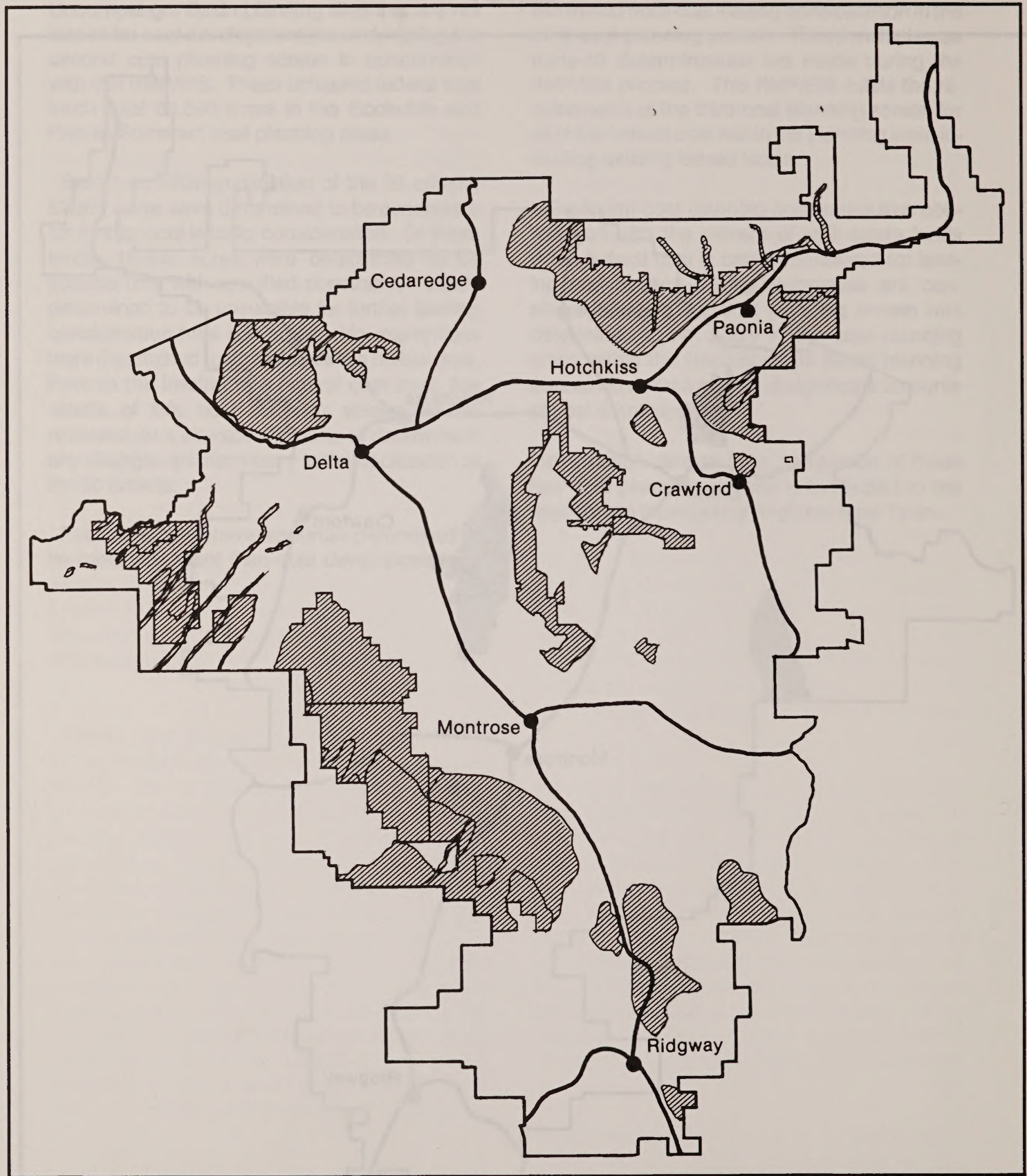

LIMITED: Areas Where Vehicle Use Will Be Limited to Designated Roads and Trails, Either Seasonally or Year-round.

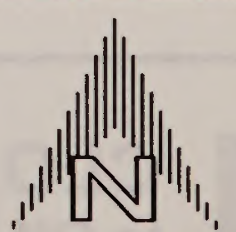

Scale: $1^{\prime \prime}=10$ Miles 


\section{APPENDIX D \\ Fire Suppression Category \\ Conditional Suppression Areas}

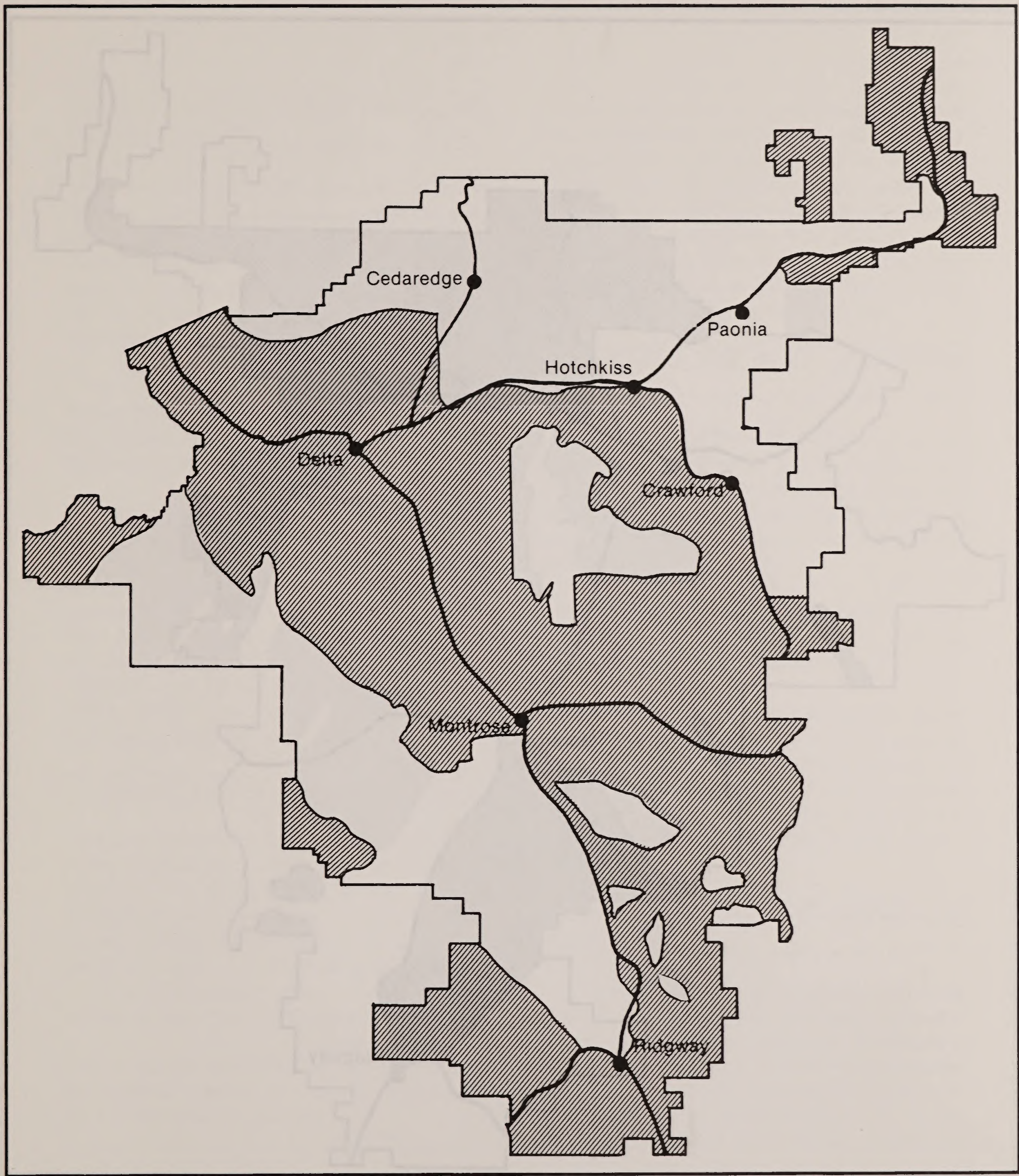

MAP D - 1

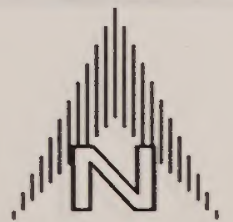




\section{APPENDIX D}

\section{Fire Suppression Category \\ Intensive Suppression Areas}

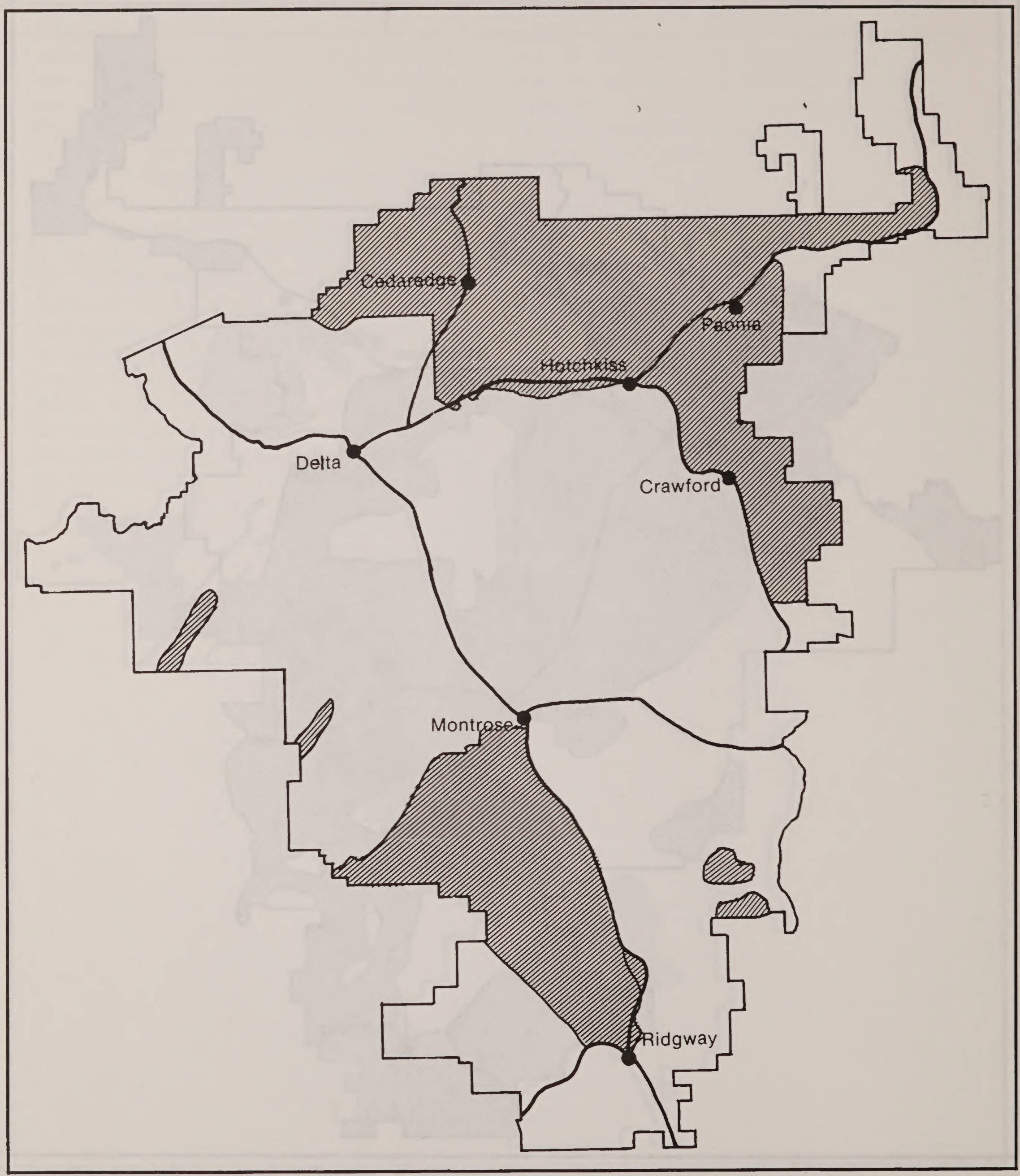

MAP D - 2

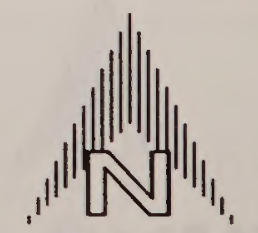




\section{APPENDIX D \\ Fire Use Category \\ Planned or Natural Ignitions}

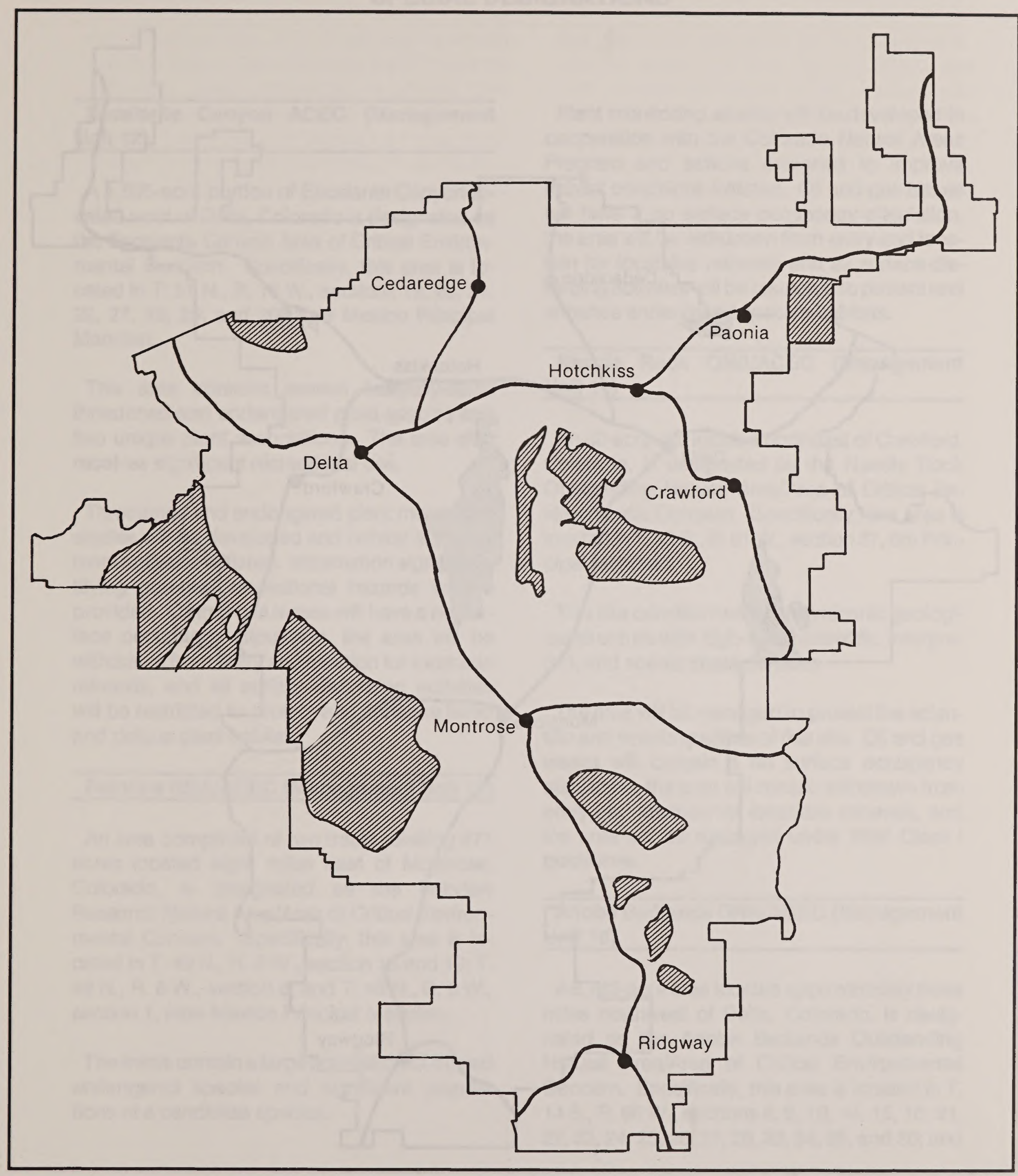

MAP D - 3

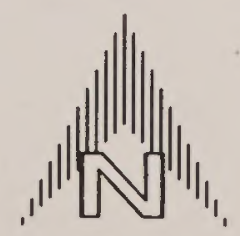

Scale: $1^{\prime \prime}=10$ Miles 


\section{APPENDIX D \\ Fire Use Category \\ Natural Ignitions Only}

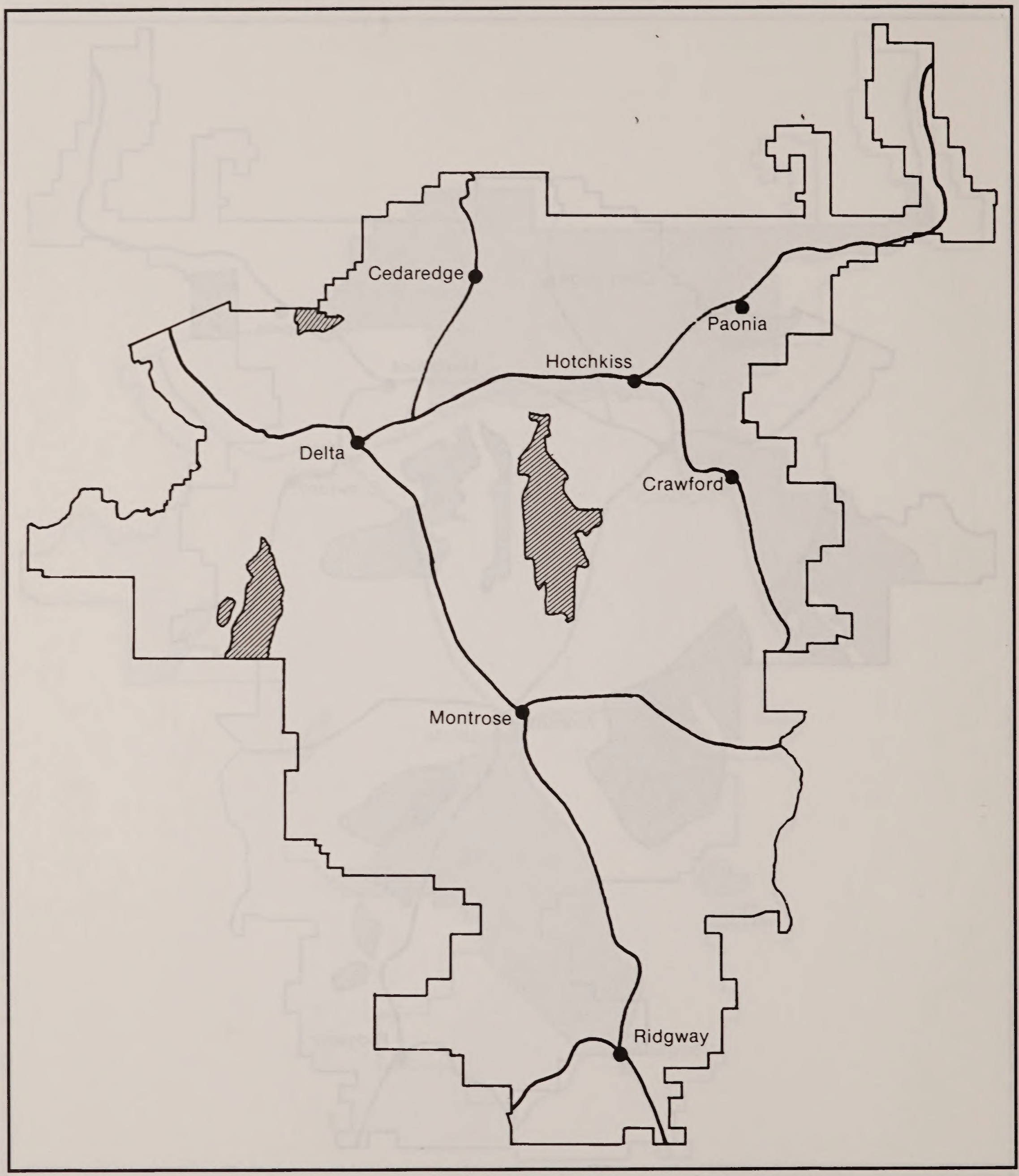

MAP D - 4

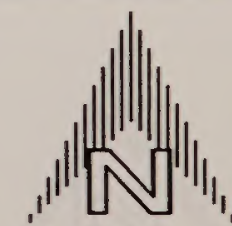

Scale: $1^{\prime \prime}=10$ Miles 


\section{APPENDIX E}

\section{SPECIAL DESIGNATIONS}

\section{Escalante Canyon ACEC (Management Unit 12)}

A 1,895-acre portion of Escalante Canyon located west of Delta, Colorado is designated as the Escalante Canyon Area of Critical Environmental Concern. Specifically, this area is located in T. 51 N., R. 13 W., sections 19, 20, 21, $22,27,28,29$, and 30 , New Mexico Principal Merldlan.

This area contains several federally-listed threatened and endangered plant species and two unique plant associations. The area also receives significant recreational use.

Threatened and endangered plant monitoring studies will be developed and habitat improvement activities initiated. Information signs identifying potential recreational hazards will be provided. Oil and gas leases will have a no surface occupancy stipulation, the area will be withdrawn from entry and location for locatable minerals, and all surface-disturbing activities will be restricted to protect and enhance listed and unique plant habitat.

Fairview RNA/ACEC (Management Unit 13)

An area comprised of two tracts totalling 377 acres located eight miles east of Montrose, Colorado, is designated as the Fairview Research Natural Area/Area of Critical Environmental Concern. Specifically, this area is located in T. 49 N., R. 8 W., section 18 and 19; T. 48 N., R. 8 W., section 6; and T. 48 N., R. 9 W., section 1, New Mexico Principal Meridian.

The tracts contain a large population of a listed endangered species and significant populations of a candidate species.
Plant monitoring studies will be developed in cooperation with the Colorado Natural Areas Program and actions designed to improve habitat conditions initiated. Oil and gas leases will have a no surface occupancy stipulation, the area will be withdrawn from entry and location for locatable minerals and all surface-disturbing activities will be restricted to protect and enhance endangered species habitats.

\section{Needle Rock ONA/ACEC (Management Unit 14)}

An 80-acre site located northeast of Crawford, Colorado, is designated as the Needle Rock Outstanding Natural Area/Area of Critical Environmental Concern. Specifically, this area is located in T. 15 S., R. 91 W., section 27, 6th Principal Meridian.

This site consists mainly of a volcanic geological structure with high-value scientific, interpretive, and scenic characteristics.

The area will be managed to protect the scientific and scenic qualities of this site. Oil and gas leases will contain a no surface occupancy stipulation, the area will remain withdrawn from entry and location for locatable minerals, and the area will be managed under VRM Class I guidelines.

\section{Ad obe Badlands ONA/ACEC (Management Unit 15)}

A6,783-acre area located approximately three miles northwest of Delta, Colorado, is designated as the Adobe Badlands Outstanding Natural Area/Area of Critical Environmental Concern. Specifically, this area is located in $\mathrm{T}$. 14 S., R. 96 W., sections $8,9,10,14,15,16,21$, $22,23,24,25,26,27,28,33,34,35$, and 36 ; and 
Appendix

T. 15 S., R. 96 W., sections 2, 3, and 4, 6th Principal Meridian.

This area consists of Mancos shale hills and flats which, through wind and water erosion, have formed unique scenic formations. The area's soils are highly erodible and saline, resulting in high sediment loads and very saline runoff. The area also contains known and potential habitat for several endangered and threatened plant species.

The area will be managed to protect its unique scenic qualities, improve threatened and endangered species habitat, and reduce active erosion. Oil and gas leases will contain a no surface occupancy stipulation; forage utilization will be limited if necessary to reduce erosion rates; and the area will be protected from surface-disturbing activities which would degrade scenic qualities or accelerate erosion. 




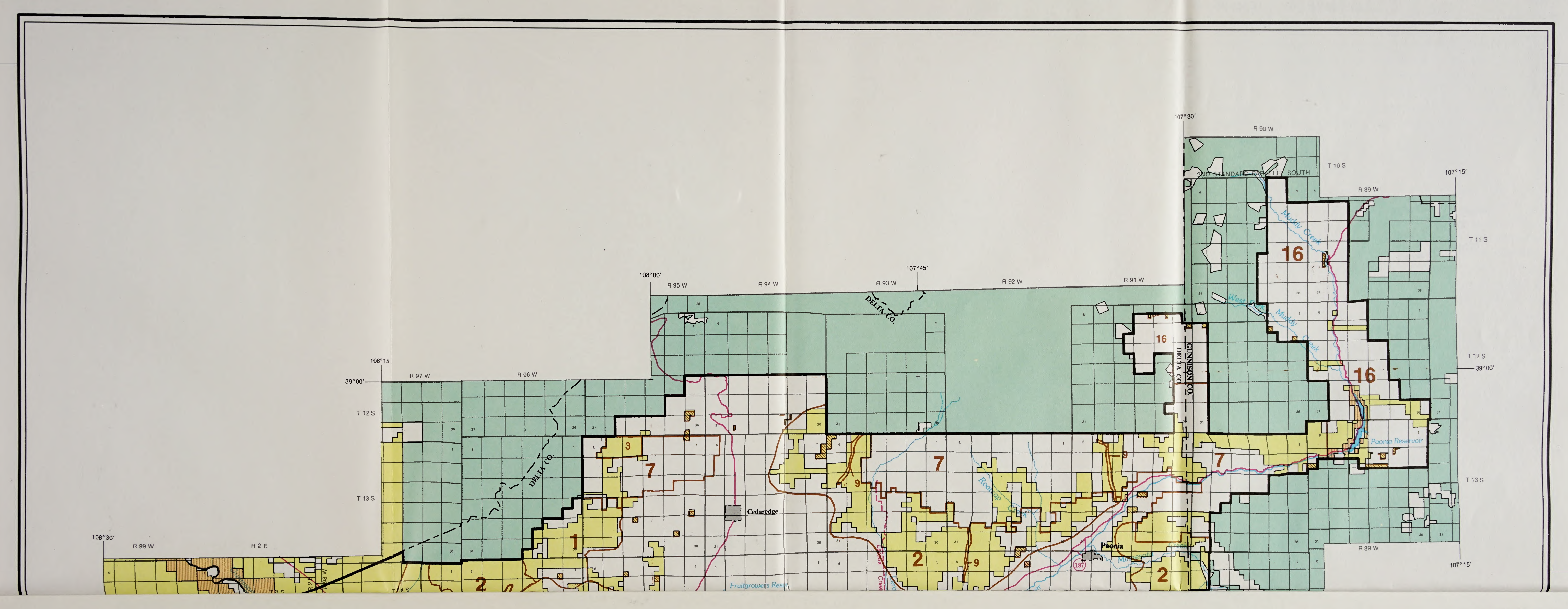




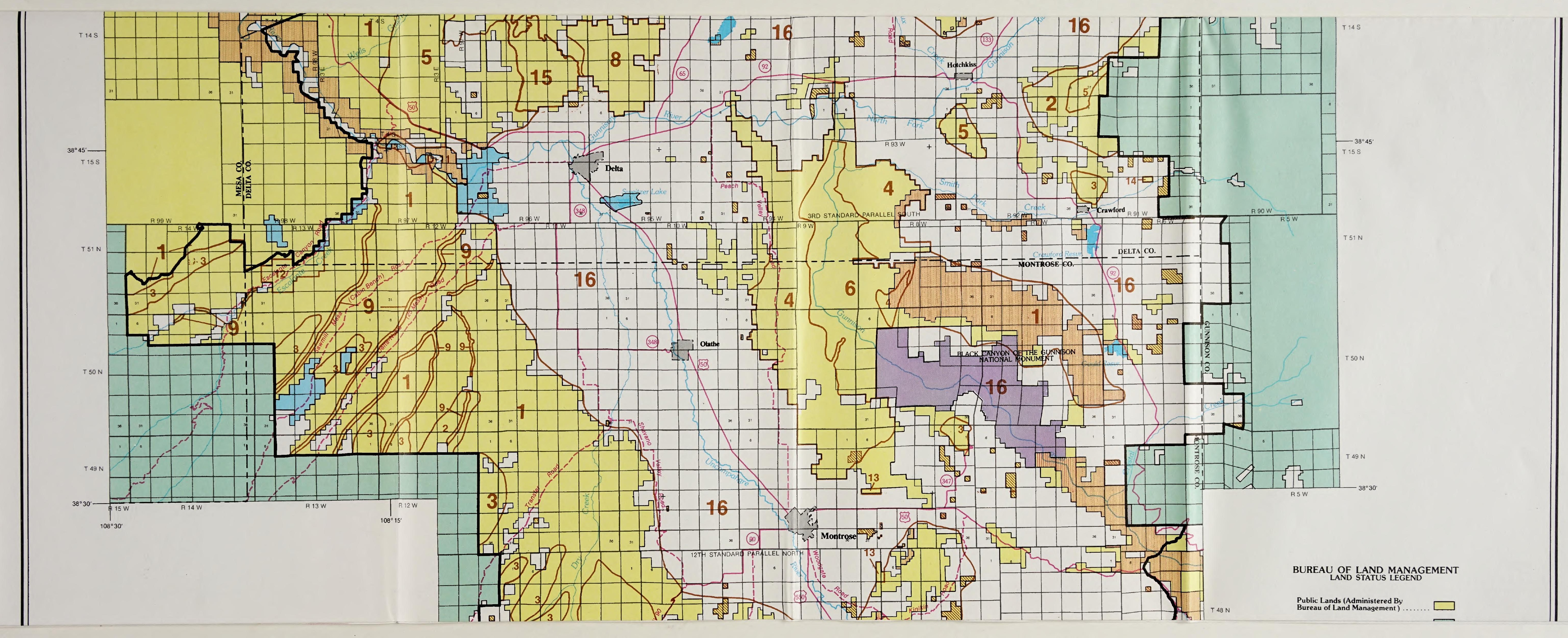



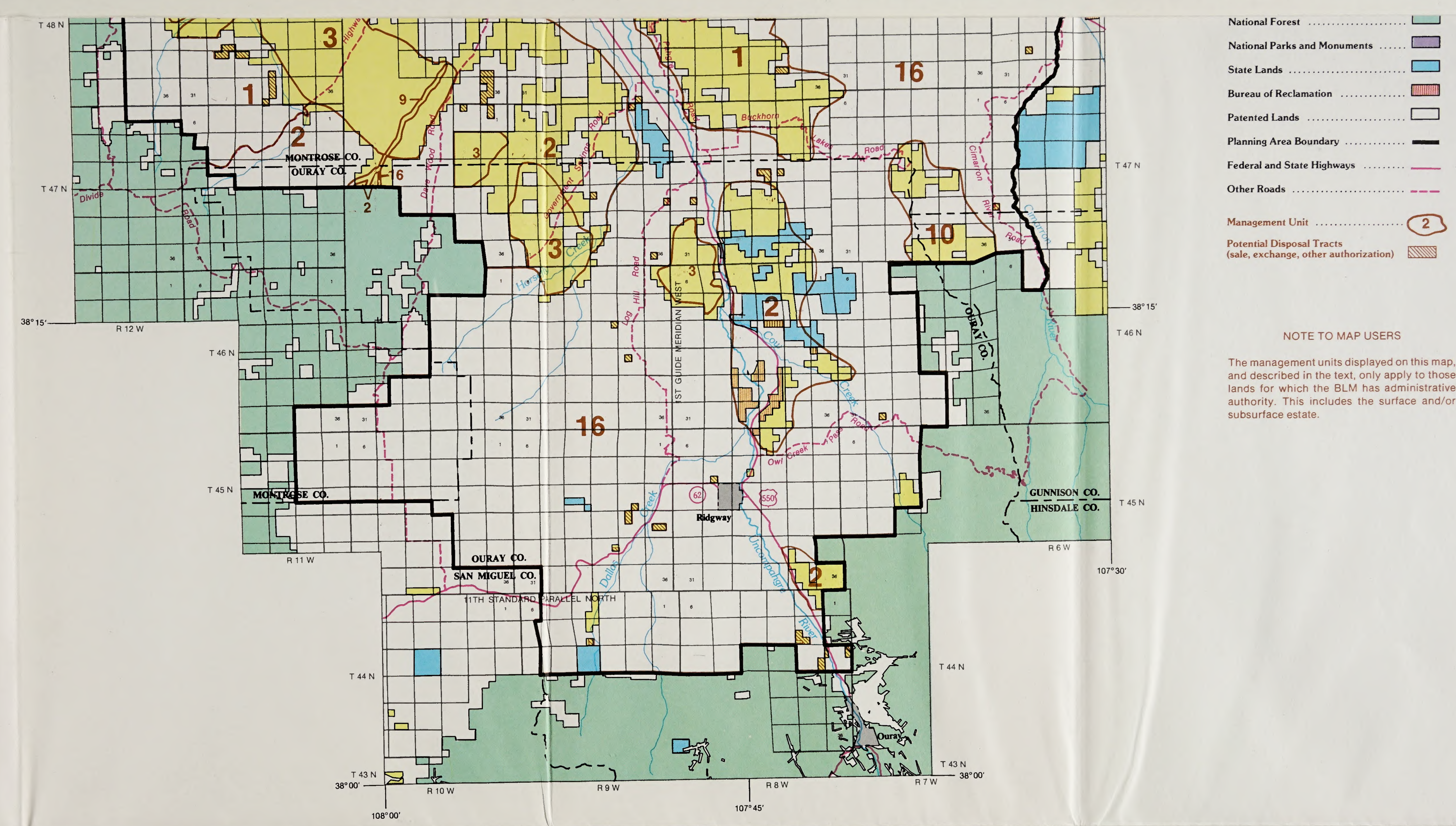

NOTE TO MAP USERS

The management units displayed on this map,
and described in the text. only apply to those

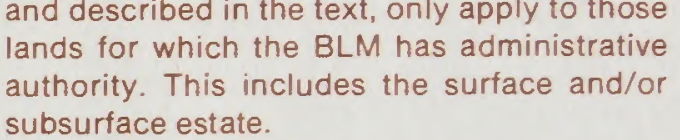


BLM Library

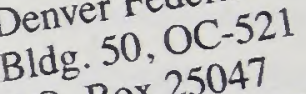

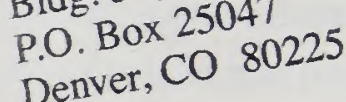



BLM Library

Denver Federal Center

Bidg. 50, OC-521

P.O. Box 25047

Denver, CO 80225 
UNITED STATES DEPARTMENT OF THE INTERIOR

BUREAU OF LAND MANAGEMENT

Uncompahgre Resource Area

2505 South Townsend

Montrose, CO 81401

OFFICIAL BUSINESS

PENALTY FOR PAIVATE USE $\$ 300$

\section{Public Lands: USA (Use, Share, Appreciate)}

